\title{
Kalistrontite, its occurrence, structure, genesis and significance for the evolution of potash deposits in North Yorkshire, UK.
}

\author{
${ }^{1 *}$ Simon J. Kemp, ${ }^{1}$ Jeremy C. Rushton, ${ }^{2}$ Matthew S.A. Horstwood and ${ }^{3}$ Gwilherm Nénert \\ ${ }^{1}$ British Geological Survey, Environmental Science Centre, Keyworth, Nottingham, NG12 5GG, UK. \\ ${ }^{2}$ NERC Isotope Geosciences Laboratory, British Geological Survey, Environmental Science Centre, \\ Keyworth, Nottingham, NG12 5GG, UK. \\ ${ }^{3}$ PANalytical B.V., Lelyweg 1, 7602 EA Almelo, The Netherlands. \\ *corresponding author sjk@bgs.ac.uk \\ +441159363448
}




\begin{abstract}
The rare mineral kalistrontite, $\mathrm{K}_{2} \mathrm{Sr}\left(\mathrm{SO}_{4}\right)_{2}$, has been discovered in exceptional quantities in exploration boreholes targeting Permian polyhalite $\left(\mathrm{K}_{2} \mathrm{Ca}_{2} \mathrm{Mg}\left(\mathrm{SO}_{4}\right)_{4} \cdot 2\left(\mathrm{H}_{2} \mathrm{O}\right)\right)$-bearing evaporite deposits in North Yorkshire, UK. The kalistrontite is associated with anhydrite, polyhalite, halite, magnesite and traces of celestine in the Fordon (Evaporite) Formation, English Zechstein 2 cycle, at depths of $\sim 1.5$ to $1.7 \mathrm{~km}$ below surface. It was first encountered here during quantitative X-ray diffraction assays of composited drill core samples over an identified 50 m interval in York Potash Ltd.'s boreholes SM6, SM9 and deflections SM9A and 9B.

X-ray diffraction including structural refinement, thermal analysis, Raman spectroscopy, petrographic examination, quantitative microanalysis and Sr isotopic analysis have been employed to fully characterise the kalistrontite and determine its genesis in order to understand its distribution and significance for the polyhalite deposits.

Petrographic examination reveals that the kalistrontite is present in two general forms. Firstly as irregularly shaped, poikilotopic millimetre-scale patches of subhedral, equant to elongate millimetrescale crystals that enclose fine, rounded, irregular anhedral and rarely euhedral crystals of anhydrite, halite and magnesite. Secondly as a vein-fill formed of an interlocking mosaic of elongate sub-millimetre scale, euhedral crystals that are compositionally zoned and again enclose fine rounded anhydrite and halite crystals at vein margins. Kalistrontite displays largely replacive contact relationships with both the earlier and generally simultaneously-formed anhydrite and halite but before at least some of the polyhalite. Vein-fill kalistrontite was deposited by mineralising fluids proceeding along fractures, patchily replacing the pre-existing low porosity anhydrite and halite. EDX microanalysis of the North Yorkshire kalistrontite indicates a purer composition than previously reported but some (5-12\% stoichiometric) substitution of Ca for Sr is identified and directly linked to petrographic textures identified during backscattered scanning electron imaging.
\end{abstract}


Improved resolution XRD data for the kalistrontite is comparable to that previously published, with similar unit cell dimensions $\left(a=5.45826(5) \AA, c=20.8118(2) \AA, \alpha=90^{\circ}, \beta=90^{\circ}, \gamma=120^{\circ}\right.$, cell volume $=$ 536.968(3) $\AA^{3}$ ) and Space Group; $R \overline{3} m(166)$, despite the limited Ca substitution for Sr. Thermal behaviour, published for the first time, shows that kalistrontite is essentially stable from ambient to $\sim 960^{\circ} \mathrm{C}$. Melting occurs from $\sim 960^{\circ} \mathrm{C}$ to $1430^{\circ} \mathrm{C}$ with a resulting weight loss of $62.57 \%$, accompanied by the evolution of $\mathrm{SO}_{2}$. Minor endothermic features are tentatively ascribed to the boiling of $\mathrm{K}$ from surface sites.

The first published Raman spectrum for kalistrontite shows a major frequency shift at $968 \mathrm{~cm}^{-1}$ with minor features of decreasing intensity at $458,617,1095,1152,650,170$ and $127 \mathrm{~cm}^{-1}$.

Consistent ${ }^{87} \mathrm{Sr} /{ }^{86} \mathrm{Sr}$ values for kalistrontite and anhydrite (mean, $0.707014 \pm 0.000010,2 \mathrm{SE}$ and $0.707033 \pm 0.000020,2 \mathrm{SE}$, respectively) along with very similar values obtained for the polyhalite are indicative of Late Permian seawater in an open environment with very limited evidence of basin constriction or Sr contribution from hydrothermal or meteoric source(s). When compared to the LOWESS global curve, the ${ }^{87} \mathrm{Sr} /{ }^{86} \mathrm{Sr}$ values suggest a consistent formation date of $255 \pm 2 \mathrm{Ma}$ (late Wuchiapingian), the first published date for the EZ2 deposits in North Yorkshire.

Diagenetic processes, particularly the late-stage supply of K- and Sr-rich fluid, must have proceeded extensively in the North Yorkshire deposits. However these show only limited spatial development, within the shelf zone on the margins of the main polyhalite deposit.

The K-rich nature ( $26.3 \mathrm{wt} \% \mathrm{~K}_{2} \mathrm{O}$ ) of kalistrontite, compared to other K-bearing evaporite minerals (e.g. kainite $18.9 \%$ wt $\% \mathrm{~K}_{2} \mathrm{O}$, carnallite $17.0 \mathrm{wt} \% \mathrm{~K}_{2} \mathrm{O}$, polyhalite $15.6 \mathrm{wt} \% \mathrm{~K}_{2} \mathrm{O}$ ), has a significant effect on borehole gamma-ray response (303 compared to 229, 200 and 185 API units respectively) and therefore considerable implications for evaporite deposit modelling and the determination of deposit-grade.

Understanding the character and distribution of kalistrontite is necessary to modelling the nature, extent and grade of the world's richest-known deposit of polyhalite. York Potash Ltd have recently 
commenced construction of the $\$ 3.0 \mathrm{bn}$ Woodsmith Mine to support large-scale polyhalite production, promising the creation of thousands of jobs and a boost to both local and national economies. First production is scheduled for late 2021.

Keywords: kalistrontite, North Yorkshire, evaporite, Permian, Zechstein, X-ray diffraction, petrography, Sr isotope 


\section{INTRODUCTION}

Kalistrontite $\left(\mathrm{K}_{2} \mathrm{Sr}\left(\mathrm{SO}_{4}\right)_{2}\right)$ was first described from Permian strata at Alshtan, in the Ural Mountains, Russia (Voronova, 1962) and has since only been encountered at a few localities, worldwide: Permian rocks from Pleismar, Germany (Bader \& Böhm, 1966; Bader, 1967); the Pleistocene geothermal field at Latium, Italy (Maras, 1979); the Triassic Nongle salt deposit, Sichuan Province, China (Min Mo, 1987); Recent deposits from the Omongwa Pan, Namibia (Mees, 1999), Miocene evaporites from the Emet Basin, Turkey (Garcia-Veigas et al., 2011) and Pleistocene salt lake deposits from the Tarim Basin, Xinjiang, China (Sun et al., 2013).

The Italian example uniquely occurs within a geothermal field but the remaining localities are all found within Permo-Triassic, Neogene or younger sedimentary evaporite deposits. Typically the kalistrontite has developed as an early diagenetic precipitate from high $\mathrm{K}$ - and $\mathrm{SO}_{4}$-rich brines or via the alteration of precursor evaporite minerals such as sylvite or celestine. In all cases, the kalistrontite constituted only a minor or mostly trace component of the host rock.

Recently, significant quantities of kalistrontite have been identified during mineralogical characterisation of core materials from exploration boreholes sited to intercept Permian evaporite deposits in North Yorkshire, UK (Smith et al., 2014; Kemp et al., 2016). Here the primary exploration target is the polyhalite $\left(\mathrm{K}_{2} \mathrm{Ca}_{2} \mathrm{Mg}\left(\mathrm{SO}_{4}\right)_{4} \bullet 2\left(\mathrm{H}_{2} \mathrm{O}\right)\right)$-bearing Fordon (Evaporite) Formation at depths of $\sim 1.5$ to $1.7 \mathrm{~km}$ below surface. Polyhalite is being mined and marketed as a slow-release, multi-element fertiliser lacking chloride. Indications from boreholes and seismic surveys suggest that the region contains the world's largest known resource of polyhalite (Smith et al., 2014; Kemp et al., 2016).

The presence of such quantities of the rare kalistrontite is in itself noteworthy, albeit seemingly localised, but it also raises important questions for the genesis of the North Yorkshire Permian potash deposit. An understanding of kalistrontite distribution and characteristics particularly its relationship to other evaporite minerals, is important to understanding the evolution of the deposit. Although trace 
quantities of celestine have been noted in the sequence (Kemp et al., 2016), the lack of significant quantities of this and other Sr-bearing minerals has raised various theories as to the possible source of the Sr. While a Permian seawater origin would seem most likely, continental erosion or intrusive igneous derivations have not yet been disproved (Kemp et al., 2016). In addition, knowledge of the distribution of kalistrontite is essential in order to correctly interpret the borehole gamma-ray response and geochemistry components of the exploration programme.

In this paper we describe this new occurrence of kalistrontite, its characterisation, distribution and genesis and significance for the potash deposits of North Yorkshire. 


\section{GEOLOGY AND POTASH EXPLORATION}

The late Carboniferous Variscan Orogeny produced a widespread unconformity and a series of deep sedimentary basins in areas now occupied by the North and Irish seas (Ruffell \& Shelton, 2000). During the late Permian, a postulated and rapid glacio-eustatic rise in sea level inundated these desertsurrounded basins to form the Zechstein and Bakevellia seas (Smith, 1995). The coincident creation of barred basins with sills close to global sea levels together with variations in eustacy, sedimentation rate, transgression, regression and periodic bar emergence was responsible for the deposition of thick sedimentary sequences including a wide range of carbonates and evaporites (Smith, 1995).

Five Permian evaporite cycles (EZ1 to EZ5) were developed in the north west corner of the epicontinental Zechstein Basin where it now occurs in North Yorkshire, UK (Figs 1, 2 and Kemp et al., 2016, Fig 2). Each cycle represents a passage from low to high salinity, traditionally thought to reflect progressively greater evaporation and the shallowing of either the whole basin or its margins (Smith \& Taylor, 1992). Alternatively a sequence stratigraphic model from lowstand gypsum, halite and potash through transgressive and highstand shallow water carbonates suggests a complete reverse of the traditional interpretation (Tucker, 1991).

Sylvite ( $\mathrm{KCl})$ deposits from cycles EZ3 and EZ4 have been exploited at the Boulby Mine (Fig. 1) since the late 1960s, primarily for agricultural fertiliser but with an important by-product of rock salt (halite, $\mathrm{NaCl}$ ), used for de-icing roads in winter conditions. More recently, attention has focussed on the deeper, polyhalite-bearing EZ2 cycle as an alternative potash resource (Fig. 2).

Three subcycles have been recognised in the EZ2 Fordon (Evaporite) Formation with a characteristic mineral zonation (Stewart, 1949, 1963). The Lower Subcycle, deposited in a basin with variable topography from a shallow water 'shelf zone' to a deep water 'basin zone', contains no known potash occurrences. The polyhalite-bearing Middle Subcycle includes a large volume of halite-dominated, basin-fill evaporites that infilled the shelf-basin topography and therefore displays a considerable 
thickness variation. The Upper Subcycle formed in uniformly shallow water conditions with no clear distinction between shelf and basin and hosts the sylvite-bearing Gough Seam (Kemp et al., 2016).

The precise correlation of the polyhalite-bearing sulphate deposits between the shelf and basin zones remains ambiguous. At the present time the deposit is referred to as the Shelf Seam in the Shelf Zone, and Basin Seam in the Basin Zone, with a Transition Zone across the ramp and in its vicinity where great thicknesses of polyhalite and anhydrite occur with varying amounts of early diagenetic, displacive halite (Kemp et al., 2016).

It is currently assumed that the polyhalite is almost entirely secondary, resulting from replacement reactions between freshly deposited gypsum/anhydrite muds on the sea bed, with dense, bottom flowing, K-Mg-rich brines (Smith et al., 2014; Kemp et al., 2016). A similar very early replacement of gypsum/anhydrite has been described for polyhalite deposits elsewhere e.g. the Zechstein of northern Poland (Peryt et al., 1998) and Russia (Peryt et al., 2005) and the Carlsbad Region, New Mexico (Barker \& Austin, 1993).

York Potash Ltd.'s exploration boreholes were cored from the EZ5 Littlebeck (Anhydrite) Formation through to the EZ2 Kirkham Abbey Formation and complimented with a suite of geophysical logs (Fig. 2). 


\section{MATERIALS AND METHODS}

\section{Materials}

Kalistrontite was first identified in North Yorkshire using X-ray diffraction (XRD) techniques on composited, core samples from York Potash Ltd.'s exploration boreholes: SM6 (Newton House Plantation, NZ 88670 01660) and SM9 (May Beck, NZ 89711 03121) including the 50 m offset cores (SM9A, SM9B)(Figs. 1, 2 and 3)(Kemp et al., 2016).

The kalistrontite is developed over a 50 m interval (SM6, 1584.20 - 1594.61 m; SM9, 1512.04 1567.16 m; SM9A, 1509.57 - 1566.68 m; SM9B, 1508.19 - 1570.77 m), within the Shelf polyhalite seam in the Shelf zone of the conceptual model for the deposit (Fig. 2). XRD analysis detected that kalistrontite formed more than $50 \%$ of the mineral assemblage in parts of the sampled interval from borehole SM6 but a smaller proportion (<10\%) in boreholes SM9, SM9A and SM9B (Supp. Table 1, Figs. 3 and 4).

\section{Sample preparation}

To provide more detailed characterisation, separation techniques were applied to isolate pure kalistrontite separates for further XRD and thermal analyses.

Firstly, halite was removed with deionised water on a reciprocal shaker overnight and decanting the chloride-rich supernatant. Otherwise, the remaining kalistrontite and gangue minerals (generally polyhalite, magnesite and anhydrite) exhibit very similar hardnesses ( 2 ), colour (colourless, white or grey) and display a vitreous lustre and brittle-conchoidal fracture (Chang et al., 1996). To exploit the marginal difference in their relative specific densities (kalistrontite 3.2, polyhalite 2.77 , magnesite 3.0

and anhydrite $2.97 \mathrm{~g} / \mathrm{cm}^{3}$ ), samples were dispersed in and separated using a diiodomethane (methylene iodide, $\mathrm{CH}_{2} \mathrm{I}_{2}$ ) heavy media (Larsen et al., 1952; Strong \& Driscoll, 2016) adjusted to an s.g. of $3.1 \mathrm{~g} / \mathrm{cm}^{3}$ using acetone. However, XRD analysis of the isolated heavy separates revealed contamination of the kalistrontite with trace amounts of anhydrite. Cleaner kalistrontite for detailed XRD and thermal 
analysis characterisation was therefore isolated by hand-picking grains under an optical microscope, before hand-grinding to a powder in an agate pestle and mortar.

In addition, thick $(>30 \mu \mathrm{m})$ polished thin-sections were prepared for petrographic and isotopic analysis by initially impregnating with blue-dyed epoxy-resin under vacuum in order to stabilise friable or unstable material (Fig. 4). The blue dye enables any natural porosity or fracturing to be identified and distinguished. To ensure preservation of water soluble phases, the sections were lapped and polished under alcohol.

\section{X-ray diffraction (XRD)}

To ensure a totally random orientation for XRD analysis, powdered kalistrontite was loaded into borosilicate glass capillary tubes (external diameter $0.3 \mathrm{~mm}$, wall thickness $0.01 \mathrm{~mm}$ ). XRD analysis was carried out at room temperature using a Debye-Scherrer geometry, PANalytical Empyrean diffractometer. For optimal data collection, hard radiation was used (high resolution Mo tube) with an incident beam focussing mirror and a GaIPIX ${ }^{3 D}$ detector. Soller slits of 0.02 rad were used for the finest resolution.

The capillary was rotated at a speed of 5 revolutions/second and scans performed in the range 5$90^{\circ} 2 \theta$ with a step size of $0.007^{\circ} 2 \theta$. A variable counting time strategy was employed to increase the counting statistics. Diffraction data were analysed, reduced and the structure determination produced using the HighScore software suite, version 4.6 (Degen et al. 2014). The XRD pattern was indexed using the program Ito (Visser, 1969) run via the positions of 20 diffraction peaks. A Pawley fit was carried out within the HighScore software in order to extract the peak intensities. The space group search using the systematic absences was completed using the program ExtSym (Markvardsen et al. 2008). The structure determination was performed using the charge flipping method using the program Superflip (Palatinus and Chapuis 2007). Superflip yielded all the atomic positions within one single run. Finally, Rietveld 
refinement was employed to complete the structure determination. All these steps were carried out using the HighScore suite, version 4.6 (Degen et al., 2014).

\section{Thermal analysis}

Separated kalistrontite samples were also analysed using thermogravimetry (TGA), simultaneously measuring the mass change, thermal changes (exothermic or endothermic, differential thermal analysis, DTA) together with characterisation of any evolved gases (evolved gas analysis, EGA).

For this, $20 \mathrm{mg}$ portions of powdered sample were heated in a $150 \mu$ l alumina crucible from 30 to $1500^{\circ} \mathrm{C}$ in a Mettler-Toledo TGA/SDTA $851^{\mathrm{e}}$ system coupled to a Pfeiffer Vacuum ThermoStar mass spectrometer. The equipment was controlled and thermal analysis data analysed using the MettlerToledo STARe software suite. A gas flow of $80 \mathrm{ml} /$ minute $\mathrm{N}_{2}$ and a slow heating rate of $5^{\circ} \mathrm{C} / \mathrm{minute}$ were selected.

\section{Petrographic analysis}

The thin sections were scanned at 1200 ppi using a flatbed scanner and examined under plane polarised light $(P P L)$, cross-polarised light $(X P L)$ and reflected light $(R L)$ conditions using a Zeiss Axio Imager A2m microscope.

Further examination was undertaken using a FEI Company Quanta 600 environmental scanning electron microscope (SEM) equipped with an Oxford Instruments INCA Energy 450 energy-dispersive Xray microanalysis (EDX) system using a $50 \mathrm{~mm}^{2}$ Peltier-cooled silicon drift X-ray detector (SDD). Uncoated sections were analysed under partial vacuum conditions ( 0.45 Torr chamber pressure, $\mathrm{H}_{2} \mathrm{O}$ atmosphere) with $20 \mathrm{kV}$ accelerating voltage. Photomicrographs were collected under backscatter electron (BSE) and secondary electron (SE) imaging conditions. The EDX systems were used for qualitative phase identification and, under the operating conditions used, are capable of detecting elements from $C$ to $U$ with a detection limit of between 0.1 to 0.3 wt\% for most elements. 


\section{Quantitative microanalysis}

Prior to isotopic and quantitative analysis, the sections were carbon-coated to a thickness of $25 \mathrm{~nm}$. Quantitative microanalysis was performed using the SEM and EDX equipment described above, operating under high vacuum, with $20 \mathrm{kV}$ accelerating voltage at spot size 5 (nominal beam current $1.2 \mathrm{nA})$. An EDX livetime of $30 \mathrm{~s}$ and a process time of $4 \mathrm{~s}$ resulted in analytical deadtimes of $\sim 25 \%$. The EDX was standardised and standards $\left(\mathrm{SrSO}_{4}, \mathrm{KCl}, \mathrm{SrTiO}_{3}\right)$ were run in parallel with the study samples.

\section{Raman spectroscopy}

Micro Raman spectroscopy analysis of thin section SSK65000 was performed using a Horiba Jobin Yvon LabRAM HR Raman spectrometer. Spectra were collected over the range $60-1200 \mathrm{~cm}^{-1}$ (1 second integration time, 8 accumulations) using a $785 \mathrm{~nm}$ laser at $24 \mathrm{~mW}$ power, a 50x objective lens and a $300 \mu \mathrm{m}$ confocal pinhole. To simultaneously scan a range of Raman shifts, a 600 lines $\mathrm{mm}^{-1}$ rotatable diffraction grating along a path length of $800 \mathrm{~mm}$ was employed. Spectra were acquired using a Synapse CCD detector (1024 pixels) thermoelectrically cooled to $-60{ }^{\circ} \mathrm{C}$. The instrument was calibrated using the zero-order line and a standard $\mathrm{Si}(100)$ reference band at $520.7 \mathrm{~cm}^{-1}$. The spectral resolution in this configuration is $\sim 0.7 \mathrm{~cm}^{-1}$.

\section{Sr isotopic analysis}

Sr isotopic compositions were determined using a ThermoScientific Neptune Plus multi-collector inductively coupled plasma mass spectrometer (MC-ICP-MS) coupled to an ESI (New Wave Research Division) NWR193UC excimer laser ablation (LA) system fitted with a TV2 two-volume ablation cell. Analysis metadata are shown in Supp. Table 2. The instrument was run in dry plasma mode with a Cetac Technologies Aridus II desolvating nebuliser providing the Ar make-up gas to the He carrier gas from the ablation cell. The instrumental set-up was tuned for low oxides (e.g. torch pulled back, $\mathrm{N}_{2}$ from the desolvator, etc.) with standard ' $\mathrm{H}$ ' geometry sample and skimmer cones on the interface. This set-up reduced detection efficiency for $\operatorname{Sr}(0.0375 \%, 36 \mathrm{~V} / \mathrm{ppm} @ 53 \mathrm{ul} / \mathrm{min})$ but helped to ensure that any 
potential molecular or doubly charged interferences (Woodhead et al., 2005; Horstwood et al., 2008;

Lewis et al., 2014) were kept to a minimum.

Initial ablation experiments demonstrated that no $\mathrm{Rb}$ was present in either the kalistrontite or anhydrite, there were no discernible peaks at half mass positions, and no discernible $\mathrm{Kr}$ or REE. Data were obtained in a single static acquisition with mass 86 on the axial collector. NBS987 solution reference material was run before and after the analysis session. Data were collected using a timeresolved analysis approach with analyses of 60 second duration, and processed using the lolite v. 3 data reduction software. A modern marine mollusc shell was run before and after the sample materials for validation, in the absence of a validation material with the same matrix as the samples, and was ablated using a $100 \mu \mathrm{m}$ spot, $4 \mathrm{~Hz}$ and $2.3 \mathrm{~J} . \mathrm{cm}^{-2}$ laser fluence. Anhydrite samples were ablated similarly but kalistrontite samples were ablated using a $25 \mu \mathrm{m}$ laser spot due to their increased Sr contents. A 60 second OPZ measurement was taken periodically $(n=17)$ prior to laser analysis and subtracted as 'baseline' in lolite. The 'Sr_isotope_CaAr' DRS was used to correct for isobaric interferences and mass bias. At such low amounts of Rb, the Rb mass bias was assumed to be the same as that for Sr. The same assumption was made for any bias differences for the CaAr correction. No uncertainty propagation has been applied to the data but all data sets have an acceptable MSWD relative to the number of analyses, indicating the absence of data scatter and thereby suggesting the measurement uncertainties alone are sufficient. 


\section{RESULTS}

\section{XRD analysis}

The generated XRD data shows a general agreement with the ICDD (ICDD, 2015) standard pattern 00029-1049 for a synthetically-produced kalistrontite (Morris et al., 1977). The new analysis presented here, with the improved resolution available from modern diffractometers and detectors, identified a total of 18 'new' peaks in the scan range and shows slightly different peak positions and relative intensities to the previously published peak data (Table 1).

Indexing of the powder XRD pattern confirms a trigonal cell and a $R \overline{3} m(166)$ space group determined using a full profile pattern-matching routine. Unit cell parameters of $a=5.45826(5) \AA, c=$ $20.8118(2) \AA, \alpha=90^{\circ}, \beta=90^{\circ}, \gamma=120^{\circ}$, cell volume $=536.968(3) \AA^{3}$ closely match those of Voronova (1962). All the atoms were found using the Superflip program, including the lighter oxygen atoms. Rietveld refinement confirmed the quality of the structural model determined from charge flipping, as shown by the resulting fit (Fig. 5). The resulting crystallographic coordinates and structural details are summarised in Table 2. The final Rietveld refinement gives rise to a good fit of the data with reasonable statistics $\left(R_{w p}=1.2 \%, G o F=2.5\right)$ and meaningful $B_{\text {iso. }}$. Two views of the crystal structure of kalistrontite are shown in Fig. 6 and a CIF has been deposited with the Supplementary Data.

\section{Raman spectroscopy}

The Raman spectrum for kalistrontite (Fig. 7) shows the fundamental vibrational modes of the $\mathrm{SO}_{4}{ }^{2-}$ tetrahedral anion, typical for sulphate minerals (e.g. Lafuente et al., 2015), at $988 \mathrm{~cm}^{-1}\left(v_{1}\right.$, symmetric stretch, $A_{1}$ symmetry), $458 \mathrm{~cm}^{-1}\left(v_{2}\right.$, bend, E symmetry); 1095 and $1152 \mathrm{~cm}^{-1}\left(v_{3}\right.$, both asymmetric stretches, $F_{2}$ symmetry) and 617 and $650 \mathrm{~cm}^{-1}\left(v_{4}\right.$, both bends, $F_{2}$ symmetry). The Raman bands between 120 and $170 \mathrm{~cm}^{-1}$ are tentatively ascribed to be lattice vibrations between the $\mathrm{K}^{+}$and $\mathrm{Sr}^{2+}$ metal cations and the oxygen of the $\mathrm{SO}_{4}{ }^{2-}$ ions. 


\section{Thermal analysis}

To our knowledge, the thermal behaviour of kalistrontite has not been previously examined in any detail. The generated TGA and EGA profiles (Fig. 8) show its essential stability from ambient temperatures to $\sim 960^{\circ} \mathrm{C}$. Melting begins at $\sim 960^{\circ} \mathrm{C}$, confirmed by a major endothermic feature on the DTA curve. A further DTA maxima occurs at $1275^{\circ} \mathrm{C}$, and incongruent melting continues to $1430^{\circ} \mathrm{C}$ with a resulting weight loss of $62.57 \%$, accompanied by the evolution of $\mathrm{SO}_{2}$ (Fig. 8). Outwith the main melting event, minor endothermic features at $\sim 125,725$ and $805^{\circ} \mathrm{C}$ are difficult to explain but the higher temperature features may relate to the boiling of $\mathrm{K}$ from the surface of the kalistrontite.

\section{Petrography}

The kalistrontite-rich samples (as identified by XRD) from borehole SM6 examined in thin section (SSK65000 and SSK65001) are from deposits that also contain common anhydrite, lesser halite, variable amounts of polyhalite and minor magnesite. Thin section samples with lower kalistrontite contents (SSK65002-5) were also studied and all were compared to more than 160 polished thin sections produced for the wider deposit study.

The examined deposit samples have interlocking crystal mosaic structures in which there are widespread planar, geometric and sinuous patterns that are defined by variations in the content and intensity of pale brown inclusions (Fig. 9a). From EDX analyses, inclusions contain a mix of silicates and organic matter, typically with associated magnesite. Inclusion patterns include a sub-horizontal banding, outlined elongate euhedral crystal forms, millimetre-scale stellate structures (Figs. 9b, c), enterolithic channels, equant polygonal outlines (Fig. 9b) and discontinuous saw-tooth profiles. None of these inclusion patterns follow the current crystal mosaic textures. Inclusion-free areas are present as irregular millimetre to sub-centimetre scale patches and veins, most abundantly in SSK65001. Some edges to the inclusion-free patches are sharply defined. 
Kalistrontite. Where present in moderate amounts, kalistrontite is present in irregularly shaped millimetre-scale patches in an anhydrite-rich matrix, and as vein-fill (Figs. 9a, c, d). In SSK65001 it is volumetrically the dominant mineral, mainly in sub-centimetre scale partially merged irregular to blocky patches with fingered margins, but also as vein-fill. In both samples, the vein-fill and some of the patches are largely inclusion-free (Fig. 9c). In patches where inclusions are present, the kalistrontite does not disrupt their patterns.

Non-vein kalistrontite predominantly forms subhedral equant to elongate millimetre-scale crystals (Figs. 9a, 10a) that additionally enclose fine, rounded, irregular anhedral and rarely euhedral crystals of anhydrite and halite (Fig. 10a). This poikilotopic kalistrontite also encloses magnesite (Figs. 10a, b). Although the enclosed magnesite is morphologically similar to that found through the rest of the sample material, it is noticeable that crystal edges are more commonly embayed (Fig. 10b).

Vein-fill kalistrontite is present in an interlocking mosaic of elongate sub-millimetre scale, euhedral crystals (Figs. 9c, d) which commonly have edges with lower backscatter coefficient (i.e. are darker under BSE imaging) than the crystal cores (Fig. 10c). This greyscale difference reflects compositional zoning with the darker rims having higher $\mathrm{Ca}$ (and consequently lower $\mathrm{Sr}$ ) contents than the brighter centres. Vein kalistrontite is poikilotopic at its margins (Fig. 9d) where it contains the inclusion pattern (Fig. 9c) and typically encloses fine rounded anhydrite (Fig. 10d) and halite.

In a sample with a lower kalistrontite content (SSK65002), the kalistrontite is typically associated with halite patches where it is present as rounded, anhedral and embayed forms enclosed by halite (Figs. 10e, f), in some cases also by associated euhedral anhydrite. Where the kalistrontite is present as disconnected (in thin section) patches within a halite crystal (Fig. 10e), they show common extinction under XPL, indicating that they are part of a single crystal linked outside the plane of the section.

Anhydrite. The dominant constituent of the non-kalistrontite portion of the deposit, anhydrite is primarily present as a fine (at a scale of 100 s of $\mu \mathrm{m}$ ) interlocking mosaic of blocky rectangular crystals 
(Fig. 10a), randomly oriented, some of which are more elongate. Inclusion patterns do not follow current crystal boundaries or shapes.

The anhydrite displays two types of textural relationship with respect to halite; there are clean planar to euhedral contacts, but also patches of embayed anhydrite and fine rounded anhydrite in halite (both types are shown in Fig. 10a). Anhydrite crystal margins are commonly embayed and truncated by kalistrontite (Figs. 10a, d). Additionally, very fine (10 $\mu \mathrm{m}$ scale) rounded patches enclosed within kalistrontite are more abundant approaching contacts between the two phases, and euhedral kalistrontite locally extends into anhydrite (Fig. 10d). There are, however, some euhedral anhydrite crystals enclosed within vein-fill kalistrontite (Fig. 10d) and within halite patches (Fig. 10e). The anhydrite occasionally contains scattered clusters of rounded to tear-drop shaped $<50 \mu \mathrm{m}$ (commonly $<10 \mu \mathrm{m})$ celestine.

Halite. A minor phase in the examined samples, halite mainly occurs as a vein-fill both excluding and enclosing kalistrontite. As a non-vein mineral it is intergrown with anhydrite in inclusion-rich areas (Fig. 10a). Magnesite is present with similar morphologies in halite as it is in anhydrite and locally crystals bridge the two phases (Fig. 10a). Anhydrite is locally embayed by halite (Fig. 10a). In the nonvein areas, halite is embayed by kalistrontite and is present as subhedral enclosed forms within the kalistrontite adjacent to kalistrontite-halite contacts.

In sample SSK65002, which has a low kalistrontite content, there are some halite patches that contain rounded, anhedral and embayed kalistrontite. Some of these mixed halite-kalistrontite patches are cut by polyhalite (see below, Figs. 10e, f) and some also contain some elongate euhedral crystals of anhydrite (Fig. 10e), a few of which enclose fine rounded kalistrontite.

Polyhalite. A rare constituent in the examined samples, polyhalite is only present in significant proportions, and together with kalistrontite, in SSK65002. In this sample it is present as mm-scale (2-5 mm long) bladed crystals in clusters that cut across the inclusion patterns, halite-anhydrite ground 
mass, halite-kalistrontite patches and also enclose rare anhedral kalistrontite (Figs. 10e, f). Varied backscatter coefficients (BSE brightness) within the polyhalite crystals (Fig. 10e) show a concentric pattern, being darkest at crystal edges and brightest at crystal cores, corresponding to lower and higher Sr contents respectively.

Magnesite. This phase is commonly concentrated in the inclusion-rich material, together with organic matter and silicates. Magnesite is also notably absent in inclusion-free patches and veins. Most of the magnesite is present as $10-30 \mu \mathrm{m}$ thick and 100-500 $\mu \mathrm{m}$ long elongate crystals; rare longer and thicker ones are found (Figs. 10a, b, d). Most have some planar edges, many have flat ends and a few show rhombic terminations. There are two distinct types; those with smooth well-formed tabular faces and those which can have one or two rough faces. The latter type more commonly contain subhedral microcrystals of other minerals (anhydrite, halite) and encloses euhedral terminations of the former (Fig. 10b). Celestine is enclosed in trace amounts in both types. Rare magnesite crystals comprise thin euhedral rims enclosing anhydrite and halite, and containing fine, rounded magnesite. Magnesite is present as single crystals, cruciform pairs and irregular clusters (Figs. 10a, b). Magnesite presents planar faces to all major minerals except kalistrontite, where they are commonly embayed (Fig. 10b). None of the magnesite crystals enclose kalistrontite.

Celestine. A trace but widespread constituent, predominantly present as fine scattered rounded to tear-drop and thinner elongate forms, commonly in clusters, enclosed by all other significant mineral phases (kalistrontite, anhydrite, halite and magnesite).

\section{Paragenesis}

The textures and inter-mineral relationships observed suggest a complex paragenetic sequence in these rocks. However, it is not the purpose of this paper to present a complete and detailed sequence, rather to place the kalistrontite formation in the context of major events, particularly with respect to polyhalite development. 
The pale brown inclusion patterns are interpreted to be relict syn-depositional textures originally developed by silicate fines and organic matter collecting / developing on deposit surfaces and infiltrated into the immediate sub-surface. The polygonal, saw-tooth, stellate and elongate forms formed around a variety of crystal types and structures from the primary deposit mineralisation, but probably largely around the gypsum and / or anhydrite. Outlined areas with overall planar textures are interpreted as deposit surfaces, whilst those with enterolithic textures are interpreted as sub-surface forms. The fact that these textures, particularly those outlining crystal forms, no longer bear relationships to current crystal structures and compositional boundaries shows that the deposit has been completely recrystallised. Areas free of these relict depositional textures are most likely a consequence of subsequent, subsurface displacive phase formation, soft deposit deformation, fracturing and recrystallization disruption.

Magnesite is the only phase that has a distribution that relates to the relict depositional textures described above. It has therefore either formed contemporaneously with these deposits, or through diagenetic alteration of constituents of the deposits (such as after a pre-cursor carbonate). The two types of magnesite identified suggest at least two growth stages; consequently at least some has formed diagenetically. This is further supported by the presence of inclusions of anhydrite and halite in the second type of magnesite which also encloses terminations of the first type. The absence of magnesite-enclosed kalistrontite suggests the second magnesite-forming episode pre-dates kalistrontite formation. The rare magnesites with a thin rim structure may be an end-member of the inclusion-rich type and suggest they have first formed in this style, with further formation being through in-filling growth to varying degrees.

Relationships between anhydrite, halite and kalistrontite present a largely clear relative formation sequence, with local complications suggesting the multi-stage development of halite and anhydrite. Textural relationships show that kalistrontite post-dates the majority of the halite and anhydrite. 
Kalistrontite displays largely replacive contact relationships towards the other two phases, which are embayed by it and which are also contained as subhedral to rounded relics within it, adjacent to contact edges. The halite and anhydrite are largely present in an interlocking crystal mosaic with euhedral and competitive interfaces, implying simultaneous or mostly overlapping periods of formation.

The inclusion-free veins of kalistrontite appear to be fracture-fill, with a finer and euhedral crystal structure consistent with formation into void space. This contrasts with the coarser poikilotopic forms typical of the kalistrontite present in inclusion-bearing parts of the deposit. Similar poikilotopic forms along the margins of the fracture-fill kalistrontite suggest a mechanism of the kalistrontite-mineralising fluids accessing the deposit along fractures, patchily replacing the pre-existing low porosity anhydritehalite. The presence of rare euhedral anhydrite within vein kalistrontite suggests some later anhydrite formation overlaps vein kalistrontite formation. This may have occurred at a late stage of the latter's formation; Ca-rich outer growth zones in the kalistrontite (see Fig. 10c and Geochemistry section below) suggest Ca-enrichment / Sr-depletion in the mineralising fluids at this stage.

Evidence for a later, post kalistrontite, episode of halite formation is presented by inclusion-free halite veins (also interpreted as fracture-fill) that locally truncate and enclose kalistrontite at margins where embayment textures also provide evidence for halite replacing the adjacent anhydrite. There are also local patches (in sample SSK65002) where halite embays and encloses subhedral to rounded relics of both anhydrite and kalistrontite. The euhedral anhydrite associated with this late halite, that also contains rounded kalistrontite relics, similarly suggests an episode of late anhydrite either associated with or post-dating this halite. As the polyhalite in SSK65002 cuts across the late halite and anhydrite, as well as the kalistrontite, at least some of the polyhalite has formed after all of these phases.

The presence of celestine throughout the deposit, enclosed by all other phases, suggests that it is an early phase. Its typical non-crystalline, 'bleb' form may be due to its formation during recrystallisation or transformation of the primary deposit. It is also possible that the celestine is syndepositional. 


\section{Mineral chemistry}

EDX microanalysis of the North Yorkshire kalistrontite (see Supp. Table 4 for full dataset) indicates significantly less $\mathrm{Na}_{2} \mathrm{O}, \mathrm{CaO}$ and $\mathrm{MgO}$ than has been reported in previous studies (Table 3, Supp. Fig. 1).

Anhydrite analysed in parallel with the kalistrontite (Table 3) produces stoichiometric values for $\mathrm{SO}_{3}$, and slightly low $\mathrm{CaO}$ values. The low $\mathrm{CaO}$ content is mainly due to the presence of minor $\mathrm{Sr}$ in the anhydrite (0.44 wt\% SrO; Table 3).

\section{Isotopic analysis}

${ }^{87} \mathrm{Sr} /{ }^{86} \mathrm{Sr}$ for NBS987 was $\left.0.710272+/-0.000018(2 \mathrm{SE}, 0.0000352 \mathrm{SD}, \mathrm{n}=4)\right)$. All data were normalised to the accepted value of 0.71025 . After normalisation, the modern marine shell returned a weighted mean ${ }^{87} \mathrm{Sr} /{ }^{86} \mathrm{Sr}$ of $0.709192+/-0.000020(2 \mathrm{SE}, \mathrm{MSWD}=1.1, \mathrm{n}=7)$. Sample and validation data are tabulated in Supp. Table 3 including ${ }^{84} \mathrm{Sr} /{ }^{86} \mathrm{Sr}$ data for which, for samples and NBS987, are within uncertainty of the expected ratio of 0.0565 . For the modern marine mollusc shell ${ }^{84} \mathrm{Sr} /{ }^{86} \mathrm{Sr}=0.05497+/-$ $0.00015(2 \mathrm{SE}, \mathrm{MSWD}=5.8, \mathrm{n}=7$ ) suggesting a modest over-correction of the Ca dimer in this calcium-rich material.

Combining the sample data obtained from the two sections (SM6 1590.81 and $1591.10 \mathrm{~m}$ ), the weighted average kalistrontite ${ }^{87} \mathrm{Sr} /{ }^{86} \mathrm{Sr}=0.707014 \pm 0.000010$ (2SE, MSWD $=0.96, \mathrm{n}=18$, Table 4, Fig. 11) and for the anhydrite ${ }^{87} \mathrm{Sr} /{ }^{86} \mathrm{Sr}=0.707033 \pm 0.000020(2 \mathrm{SE}, \mathrm{MSWD}=0.72, \mathrm{n}=7$, Table 4, Fig. 11). These are statistically indistinguishable. 


\section{DISCUSSION}

Significant quantities of the rare mineral kalistrontite $\left(\mathrm{K}_{2} \mathrm{Sr}\left(\mathrm{SO}_{4}\right)_{2}\right)$ have been identified in exploration borehole core samples from the Fordon (Evaporite) Formation in North Yorkshire, UK. The kalistrontite occurs within the Shelf facies polyhalite seam intercepted by boreholes SM6 and SM9 and offsets SM9A and SM9B.

\section{Mineralogy}

The North Yorkshire kalistrontite presents a purer composition than previously reported, natural occurrences (Voronova, 1962; Fleischer, 1963; Bader \& Bohm, 1966). The coarser-grained and more abundant kalistrontite from North Yorkshire is composed of greater proportions of $\mathrm{Sr}$ and $\mathrm{K}$ than the previous analyses (Table 3, Supp. Fig. 1). When compared to a stoichiometric analysis (Morris et al., 1977), the North Yorkshire kalistrontite is slightly K- and S-rich and slightly Sr-poor (Table 3, Supp. Fig. 1), although the ratio of the former two is very close (within 1 SD) to the stoichiometric ideal (Supp. Fig. 2).

Further examination of the EDX geochemical analyses shows a linear trend between the $\mathrm{Sr}$ and $\mathrm{Ca}$ contents that approximately parallels the stoichiometric mixing line for Ca substitution of $\mathrm{Sr}$ (Fig. 12). We conclude, therefore, that the Sr-poor nature of the North Yorkshire kalistrontite is due to its partial substitution by $\mathrm{Ca}$ and produces an average structural formula of $\mathrm{K}_{2.01} \mathrm{Sr}_{0.91} \mathrm{Ca}_{0.08}\left(\mathrm{SO}_{4}\right)_{2}$ (Table 3). This substitution can be directly linked to petrographic textures identifiable in BSE images (Fig. 10c) since the lower brightness kalistrontite has the highest Ca contents (Fig. 12). Typically, this Ca-enriched kalistrontite appears to have formed as a late stage compositional variation; there is also some evidence of fluctuating Ca levels during earlier formation. The atomic \% range of Ca content (0.38-0.95; mean 0.63, Fig. 12) represents $5-12 \%$ stoichiometric substitution for Sr. The Sr-Ca trend line runs below the ideal mixing line (Fig. 12), suggesting a slightly low total divalent cation content but this is off-set by a slightly higher monovalent cation $(\mathrm{K}, \mathrm{Na})$ content. 
The low and inconsistent levels of $\mathrm{Mg}$ detected in the North Yorkshire kalistrontite is most likely to result from the widespread presence of magnesite inclusions (Fig. 10b). A similar pattern is observed for $\mathrm{Na}$ content, however the absence of detectable $\mathrm{Cl}$ suggests some of the $\mathrm{Na}$ is from the kalistrontite, although the proximity of the EDX quantification $\mathrm{Cl}$ peak $(\mathrm{K} \alpha, 2.621 \mathrm{keV})$ to the major sulphur peaks $(\mathrm{K} \alpha \beta, 2.307-2.464 \mathrm{keV})$ increases the detection threshold for $\mathrm{Cl}$, so its non-detection may in part be an analytical effect.

The XRD-calculated cell parameters are close to those previously published (Morris et al., 1977) despite the limited Ca substitution identified by EDX analyses. Some of the differences noted in XRD relative intensity (Table 1) are likely to result from preferred orientation, as noted by Tissot et al. (2001) while comparing powder and single crystal XRD data for the isostructural palmierite $\left(\mathrm{K}_{2} \mathrm{~Pb}\left(\mathrm{SO}_{4}\right)_{2}\right)$.

The kalistrontite Raman spectrum is analogous to those obtained from other anhydrous sulphate species (e.g. Lafuente et al., 2015) but shows distinct variations in the position, relative intensity and multiplicity of the spectral features. For example, the principle $v_{1}$ mode observed at 1018, 1003 and $978 \mathrm{~cm}^{-1}$ in anhydrite, celestine and anglesite respectively (Nakamoto, 2009), appears at $988 \mathrm{~cm}^{-1}$ in the Raman spectrum of kalistrontite, consistent with the trend of decreasing frequency with increasing atomic mass of the associated cations (Buzgar et al., 2009).

Thermal analysis, first performed in this study, suggests that kalistrontite begins to melt at $960^{\circ} \mathrm{C}$, in common with other simple, water-free sulphates (Vassilev et al., 1995; Földvári, 2011). Decomposition temperatures in sulphates vary from $494^{\circ} \mathrm{C}$ (ferric sulphate, $\mathrm{Fe}_{2}\left(\mathrm{SO}_{4}\right)_{3} ; \mathrm{Mu} \&$ Perlmutter, 1981) to $1200^{\circ} \mathrm{C}$ (anhydrite, $\mathrm{CaSO}_{4} ;$ West \& Sutton, 1953). The recorded $62.57 \%$ weight loss for kalistrontite exceeds the $53.67 \%$ predicted by the stoichiometric total loss of the sulphate groups. Allowing for the mean $0.67 \%$ Ca-substitution for Sr indicated by EDX analysis, the total sulphate weight loss would be expected to be $\sim 54.5 \%$. The additional weight loss is most likely explained by the decomposition of $\mathrm{K}_{2} \mathrm{O}\left(300-350^{\circ} \mathrm{C}\right.$, 
Haynes, 2014) or even boiling of $\mathrm{K}\left(759^{\circ} \mathrm{C}\right.$; Haynes, 2014) following kalistrontite melting. SEM and EDX examination of the crucible melt residue confirmed a complete loss of $\mathrm{K}$ and provides further evidence for the K-loss phenomena established for polyhalite-bearing samples during routine slow fusion with lithium metaborate prior to geochemical analysis (Kemp et al., 2016). Minor, endothermic DTA features at 125,725 and $805^{\circ} \mathrm{C}$ are unexplained but the higher temperature peaks may reflect boiling of $\mathrm{K}$ from surface sites (Haynes, 2014).

\section{Genesis}

The kalistrontite from other evaporitic settings, although these are lakes rather than marine basins, has developed as an advanced early diagenetic precipitate from high $\mathrm{K}$ - and $\mathrm{SO}_{4}$-rich brines or via the alteration of a range of precursor evaporite minerals (Kemp et al., 2016). For example, in the Emet Basin, Turkey, K-bearing minerals including kalistrontite formed on the lake floor by the reaction of concentrated K-rich brines with pre-existing probertite $\left(\mathrm{NaCaB}_{5} \mathrm{O}_{7}(\mathrm{OH})_{4} \bullet 3\left(\mathrm{H}_{2} \mathrm{O}\right)\right)$, glauberite $\left(\mathrm{Na}_{2} \mathrm{Ca}\left(\mathrm{SO}_{4}\right)_{2}\right)$ and fontarnauite $\left((\mathrm{Na}, \mathrm{K})_{2}(\mathrm{Sr}, \mathrm{Ca}) \mathrm{SO}_{4}\left[\mathrm{~B}_{4} \mathrm{O}_{6}(\mathrm{OH})_{2}\right] \cdot 3 \mathrm{H}_{2} \mathrm{O}\right)$ as the fluids moved from the lake centre to the surrounding areas (Garcia-Veigas, 2011). In recent deposits from the Omongwa Pan, southwestern Kalahari, kalistrontite has formed by replacement of gypsum following reaction with evaporative-concentrated brines with elevated Sr but not exceptional levels of K, during periods of sustained low groundwater levels (Mees, 1999).

Our petrographic studies suggest that the North Yorkshire kalistrontite is also a diagenetic occurrence, but paragenetically relatively late, with only minor episodes of halite, anhydrite and polyhalite formation post-dating the kalistrontite. Additionally, kalistrontite has partially formed by replacing pre-existing anhydrite and halite, and there is evidence of the partial replacement of magnesite. The petrographic evidence also shows that the anhydrite and halite are themselves present after recrystallisation and / or transformation of the primary deposit mineralisation. 
The anhydrite itself contains $0.44 \mathrm{wt} \% \mathrm{SrO}$, and there are traces of celestine present throughout, but these are inadequate resources to have been a significant source for the $\mathrm{Sr}$ in the kalistrontite; both $\mathrm{Sr}$ and $\mathrm{K}$ must have primarily originated from the mineralising fluids.

Strontium isotope ratios, ${ }^{87} \mathrm{Sr} /{ }^{86} \mathrm{Sr}$, can provide important new insights into the source(s) and cycling of cations in the marine environment (Capo et al., 1998). Oceanic ${ }^{87} \mathrm{Sr} /{ }^{86} \mathrm{Sr}$ values are a function of the balance between continental weathering via riverine input, dissolution of marine carbonates and the hydrothermal exchange with mid-ocean ridge basalts (Palmer \& Elderfield, 1985). Owing to its long ( 2.5 m.y.) residence time, the $\mathrm{Sr}$ isotopic composition of the oceans is constant at any given time (Hodell et al., 1990).

Late Permian seawater ${ }^{87} \mathrm{Sr} /{ }^{86} \mathrm{Sr}$ values, obtained from brachiopods shells and conodont elements (Korte et al., 2006) and micritic limestone (Kani et al., 2008; 2013), vary from 0.7069 to 0.7072 . This compares to the more radiogenic ratio values of 0.716 (Goldstein \& Jacobsen, 1988; Veizer, 1989) and 0.702 to 0.714 (Faure, 1986) for eroded continental crust- and continental volcanic-derived Sr, respectively. Less radiogenic values are typically associated with Phanerozoic limestones $(0.707$ to 0.709, e.g. Burke et al., 1982) or mantle-derived hydrothermal sourced fluids ( 0.703, e.g. Veizer, 1989).

The North Yorkshire kalistrontite and anhydrite laser ablation ${ }^{87} \mathrm{Sr} /{ }^{86} \mathrm{Sr}$ values (mean values of $0.707014 \pm 0.000010$ and $0.707033 \pm 0.000020$ respectively) fall within the range of values reported for Late Permian seawater (Fig. 11). Similar ${ }^{87} \mathrm{Sr} /{ }^{86} \mathrm{Sr}$ values have also been measured for the polyhalite (mean $0.707038 \pm 0.000056)$ and anhydrite $(0.707027 \pm 0.000053)$ from various intervals (Basal Anhydrite, Basinal Polyhalite Seam, Sulphatic Halite, Shelf Polyhalite Seam and the Upper Anhydrite) from the York Potash exploration boreholes using a differential dissolution methodology (Warburton, 2014) (Fig. 11). No major differences were noted between the different stratigraphical zones (Warburton, 2014). 
The value and consistency of the ${ }^{87} \mathrm{Sr} /{ }^{86} \mathrm{Sr}$ measured for kalistrontite, polyhalite and anhydrite in the North Yorkshire deposits suggests that they have all formed from Late Permian seawater fluids, in an open environment with very limited evidence of basin constriction or Sr contribution from hydrothermal or meteoric source(s). In a larger study of 74 anhydrite samples from the Polish Zechstein, Late Permian seawater ${ }^{87} \mathrm{Sr} /{ }^{86} \mathrm{Sr}$ values were also measured for most of the samples with the exception of higher values from certain, generally deeper, intervals of the Bonikowo 2, Gorzów Wielkopolski IG1 and Olsztyn IG1 boreholes $(0.707163-0.708715$, mean $0.707524 \pm 0.000012$, Denison \& Peryt, 2009). These higher values were considered to record the mixing of locally large volumes of radiogenic Sr-bearing meteoric water with the marine water, particularly near the Zechstein coastline (Denison \& Peryt, 2009). A substantial meteoric contribution was also favoured for the considerable scatter shown by ${ }^{87} \mathrm{Sr} /{ }^{86} \mathrm{Sr}$ values obtained from the sub-basins of the German Zechstein and Austrian Haselgebirge evaporite cycles (Denison \& Peryt, 2009). The contrasting lack of higher ${ }^{87} \mathrm{Sr} /{ }^{86} \mathrm{Sr}$ values in North Yorkshire may result from the quiescent, sampled shelf and basin zone locations, distal from meteoric input.

Since the ${ }^{87} \mathrm{Sr} /{ }^{86} \mathrm{Sr}$ value of $\mathrm{Sr}$ dissolved in the world's oceans has varied through time in a known way (McArthur et al., 2012), the data produced from the North Yorkshire samples can also be used to date and correlate these rocks with marine sequences worldwide. The statistical LOWESS V5 fit to the ${ }^{87} \mathrm{Sr} /{ }^{86} \mathrm{Sr}$ curve (McArthur et al., 2012) presents a minima during the late Permian (late Capitanian, 259.1 - 265.1 Ma; Cohen et al., 2013) and the associated look-up table generates the possibility of two sets of dates for the minerals from North Yorkshire: kalistrontite; $265 \pm 2$ or $255 \pm 2 \mathrm{Ma}$, anhydrite $266 \pm 2$ or $255 \pm 2 \mathrm{Ma}$ and polyhalite (based on Warburton, 2014) $266 \pm 2$ or $255 \pm 2 \mathrm{Ma}$. However, on the basis of bio- and magnetostratigraphical data from The Netherlands, Germany and Poland, Szurlies (2013) concluded that the Zechstein Group dates from the mid-Wuchiapingian (duration 254.14 - 259.1 Ma, Cohen et al., 2013) and lasted only 2.8 -3.5 Myr. The North Yorkshire kalistrontite, anhydrite and 
polyhalite from the Fordon (Evaporite) Formation (EZ2) would therefore indicate the consistent, later formation date of $255 \pm 2$ Ma (late Wuchiapingian, Cohen et al., 2013).

\section{Distribution}

The higher proportion of kalistrontite present in certain intervals of the North Yorkshire deposit (reaching 51.1\% in SM6, Table 1) contrasts with the minor or trace amounts identified at the other sites, worldwide. This may simply reflect a paucity of adequate mineralogical characterisation at other locations, neglecting the presence of kalistrontite. Alternatively, the diagenetic processes outlined above, particularly the supply of K- and Sr-rich fluid, may have proceeded more extensively in the North Yorkshire deposits.

Kalistrontite has so far only been identified in two, adjacent boreholes (SM6, SM9 and offsets) in the present study, within the shelf zone on the margins of the main polyhalite deposit (Fig. 2), suggesting only localised development in a geographically restricted area. As noted by Kemp et al. (2016), kalistrontite may occur in other, legacy hydrocarbon wells but has been overlooked due to a lack of mineralogical or petrographical analysis and the difficulty of identification from core descriptions and wireline logs when intimately mixed with anhydrite and polyhalite.

The heterogeneous vertical and lateral distribution of massive kalistrontite detected in only two of the exploration boreholes is difficult to explain with a simple process. The observed selective replacement appears to negate a vertical fluid movement, either upward or downward. No underlying faulting has been identified below or connecting SM6 and SM9 (F.W. Smith pers. comm.). We therefore contend that the kalistrontite formed close to the sea bed interface via the alteration of a calcium sulphate crystal mush with dense, K- and Sr-rich bottom brines. These brines were episodically produced from either insitu, precursor mineral dissolution or a distal source to the west, updip, from the basin margin. 
Although petrographic analysis has revealed that some of the kalistrontite occurs as a microfracturefilling, we assess this to reflect relatively late-stage re-distribution (as seen in the polyhalite, elsewhere in the deposit) and not due to transient hydraulic fracturing of the lithified rock, albeit common in such a basinal margin setting (Cosgrove, 2001; Warren, 2016).

Identification of kalistrontite and its distribution is clearly important in interpreting borehole gammaray response and geochemistry in potash exploration projects. Kalistrontite contains $26.3 \mathrm{wt} \% \mathrm{~K}_{2} \mathrm{O}$ and produces a gamma-ray geophysical response of 303 API units (Edmundson \& Rayner, 1979). This compares to other K-bearing minerals commonly encountered in potash evaporite sequences such as sylvite $\left(\mathrm{KCl}, 63.2 \mathrm{wt} \% \mathrm{~K}_{2} \mathrm{O}\right.$ and $747 \mathrm{API}$ units), polyhalite $\left(\mathrm{K}_{2} \mathrm{Ca}_{2} \mathrm{Mg}\left(\mathrm{SO}_{4}\right)_{4} \cdot 2\left(\mathrm{H}_{2} \mathrm{O}\right), 15.6 \mathrm{wt} \% \mathrm{~K}_{2} \mathrm{O}\right.$ and 185 API units), kainite $\left(\mathrm{KMg}\left(\mathrm{SO}_{4}\right) \mathrm{Cl} \bullet\left(\mathrm{H}_{2} \mathrm{O}\right)_{2.75}, 18.9\right.$ wt\% $\mathrm{K}_{2} \mathrm{O}$ and $229 \mathrm{API}$ units $)$ and carnallite $\left(\mathrm{KMgCl}_{3} \bullet 6 \mathrm{H}_{2} \mathrm{O}\right.$, 18.9 wt $\% \mathrm{~K}_{2} \mathrm{O}$ and $185 \mathrm{API}$ units).

Downhole gamma-ray response has been used to assist in the characterisation of potash deposits and particularly to correlate between exploration boreholes (Nelson, 2007). As demonstrated in the York Potash boreholes, since kalistrontite has a much greater gamma-ray response than polyhalite, the presence of even small quantities of kalistrontite produces a geophysical response that could be attributed to greater proportions of polyhalite (Fig. 3). Since kalistrontite also contains a greater proportion of $\mathrm{K}$ than polyhalite, the detection of kalistrontite is required to accurately determine the true polyhalite-grade. 


\section{IMPLICATIONS}

The discovery of exceptional quantities of kalistrontite in the Fordon (Evaporite) Formation, North Yorkshire has several important implications.

Firstly this study has provided new and confirmatory XRD and crystallographic data for this rare mineral but also detailed thermal analysis, Raman spectroscopy and micro-geochemical data, not previously published. As recently endorsed by Hazen \& Ausubel (2016), the description of such rare minerals are key to understanding the diversity and disparity of Earth's mineralogical environments, extreme compositional regimes, unique crystal structures and are inherently fascinating.

The wider implications of the discovery revolve around the genesis and distribution of the kalistrontite. Sr isotopic data and petrographic study suggest that the kalistrontite formed during the late diagenetic alteration of gypsum/anhydrite by K- and Sr-rich fluids derived from Permian seawater. At present, kalistrontite development appears to be restricted to a small geographical area on the margins of the polyhalite deposit. Importantly, when compared to the LOWESS V5 seawater ${ }^{87} \mathrm{Sr} /{ }^{86} \mathrm{Sr}$ curve, the North Yorkshire Sr isotope data suggest the polyhalite, anhydrite and kalistrontite formed at $255 \mathrm{Ma} \pm 2 \mathrm{Ma}$ (late Wuchiapingian), the first published date for the EZ2 deposits.

Understanding the distribution of kalistrontite is important to the correct interpretation of downhole geophysical log responses and more importantly modelling the nature of these important polyhalite deposits and their grade.

York Potash Ltd have recently commenced construction of the $\$ 3.0 \mathrm{bn}$ Woodsmith Mine to support large-scale polyhalite production, promising the creation of thousands of jobs and a boost to the local and national economies. First production is scheduled for late 2021. 


\section{ACKNOWLEDGEMENTS}

The work presented in this paper stemmed from the initial characterisation of the York Potash deposit which involved the work of an extensive project team at the British Geological Survey, FWS Consultants and York Potash Ltd and their efforts are gratefully acknowledged. The authors would also like to express their gratitude to York Potash Ltd for permission to publish this paper. John Fletcher (BGS) is thanked for the preparation of the polished thin sections and lan Mounteney (BGS) for assistance with mineral separation. Graham Rance (Nanoscale and Microscale Research Centre, University of Nottingham) is thanked for facilitating the Raman spectroscopy. We thank Rick Smith, Javier Garcia Veigas, Tadeusz Peryt and an anonymous reviewer for their helpful comments which considerably improved this paper. SK, JR and MH publish with the permission of the Executive Director, British Geological Survey (NERC). 


\section{REFERENCES CITED}

BADER, E. (1967) The genesis of kalistrontite in the Stassfurt salt bed in the Pleismar 2/ 64 boring.

Chemie der Erde, 26, 304-321

BADER, E., AND BÖHM, G. (1966) Kalistrontit, im Flöz Stassfurt des Rossleben-Unstrut-Reviers. Chemie der Erde, 25, 253-257 (in German).

BARKER, J.M., AND AUStin, G.S. (1993) Economic geology of the Carlsbad Potash District, New Mexico. Pp. 283-291 in D.W. LoVE, J.W. HAWLEY, B.S. KuES, G.S. Austin, S.G. LUCAS, Eds., Carlsbad Region (New Mexico and West Texas), New Mexico Geological Society 44th Annual Fall Field Conference Guidebook, 357 p.

Burke, W.H., Denison, R.E., Hetherington, E.A., KoepNick, R.B., Nelson, H.F., AND Otto, J.B. (1982) Variation of seawater ${ }^{87} \mathrm{Sr} /{ }^{86} \mathrm{Sr}$ throughout Phanerozoic time. Geology, 10, 516-519.

Buzgar, N., BuZATU, A., AND SANislaV, I.V. (2009). The Raman study of certain sulphates. Annalele Stiintifice ale Universitatii, 55, 5-23

CAPO, R.C., SteWART, B.W., AND CHADWICK, O.A. (1998) Strontium isotopes as tracers of ecosystem processes: theory and methods. Geoderma, 82, 197-225.

CHANG, L.L.Y., HowIE, R.A., AND ZusSmAN, J. (1996) Deer, Howie and Zussman, Rock Forming Minerals, Volume 5B: Non-Silicates: Sulphates, Carbonates, Phosphates and Halides, 383 p. Harlow, (Longman).

Cohen, K.M., Finney, S.C., GiBBARD, P.L., AND FAN, J.-X. (2013; updated) The ICS International Chronostratigraphic Chart. Episodes, 36, 199-204. Available at

http://www.stratigraphy.org/ICSchart/ChronostratChart2017-02.pdf (accessed 13 November 2017).

COSGROVE, J.W. (2001) Hydraulic fracturing during the formation and deformation of a basin: A factor in the dewatering of low-permeability sediments. American Association of Petroleum Geologists Bulletin, $85,737-748$. 
Degen, T., SAdKI, M., BRon, E., KöNIG, U., AND NÉNERT, G. (2014) The HighScore suite. Powder Diffraction, 29, S13-S18.

DENISON, R.E., AND PERYT, T.M. (2009) Strontium isotopes in the Zechstein (Upper Permian) anhydrites of Poland: evidence of varied meteoric contributions to marine basins. Geological Quarterly, 53(2), 159166.

EDMUNDSON, H., AND RAYMER, L.L. (1979) Radioactive logging parameters for common minerals. Log Analyst, 20, 38-47.

FAURE, G. (1986) Principles of Isotope Geology, 589 p. Wiley, New York

FleisCher, M. (1963) New Mineral Names. American Mineralogist, 48, 708-709.

FÖLDVÁRI, M. (2011) Handbook of thermogravimetric system of minerals and its use in geological practice. Occasional Papers of the Geological Institute of Hungary, 213, 180 pp.

García-Veigas, J., Rosell, L., Ortı, F., GündoĞAN, I., AND HelvaCl, C. (2011) Mineralogy, diagenesis and hydrochemical evolution in a probertite-glauberite-halite saline lake (Miocene, Emet Basin, Turkey). Chemical Geology, 280, 352-364.

GOLDSTEIN, S.L., AND JACOBSEN, S.B. (1988) Nd and Sr isotopic systematics of river water suspended material: implications for crustal evolution. Earth and Planetary Science Letters, 87, 249-265.

HAYNES, W.M. (2014) CRC Handbook of Chemistry and Physics, CRC Press/Taylor and Francis, Boca Raton, FL, 95th Edition, Internet Version 2015, accessed November 2016.

HAZEN, R.M., AND AUSUBEL, J.H. (2016) On the nature and significance of rarity in mineralogy. American Mineralogist, 101, 1245-1251. 
Hodell, D.A., MeAd, G.A., AND MuelleR, P.A. (1990) Variation in the strontium isotopic composition of seawater (8 Ma to present), Implications for chemical weathering rates and dissolved fluxes to the oceans. Chemical Geology, 80, 291-307.

HoRSTWOOD, M.S.A., EVANS, J.A., AND MONTGOMERY, J. (2008) Determination of Sr isotopes in calcium phosphates using laser ablation inductively coupled plasma mass spectrometry and their application to archaeological tooth enamel. Geochimica et Cosmochimica Acta, 72, 5659-5674.

ICDD. (2015) PDF-4+ 2015 (Database), edited by Dr. Soorya Kabekkodu, International Centre for Diffraction Data, Newtown Square, PA, USA.

KANI, T., FUKUI, M., ISOZAKI, Y., AND NOHDA, S. (2008) The Paleozoic minimum of Sr-87/Sr-86 ratio in the Capitanian (Permian) mid-oceanic carbonates: A critical turning point in the Late Paleozoic. Journal of Asian Earth Sciences, 32, $22-33$.

KANI, T., HISANABE, C., AND ISOZAKI, Y. (2013) The Capitanian (Permian) minimum of Sr-87/Sr-86 ratio in the mid-Panthalassan paleo-atoll carbonates and its demise by the deglaciation and continental doming. Gondwana Research, 24, $212-221$.

Kemp, S.J., SMith, F.W., Wagner, D., Mounteney, I., Bell, C.P. Milne, C.J., GoWing, C.J.B., ANd PotTAS, T.L. (2016) An improved approach to characterise potash-bearing evaporite deposits, evidenced in North Yorkshire, UK. Economic Geology, 111, 719-742.

KORTE, C., JASPER, T., KOZUR, H.W., AND VEIZER, J. (2006) Sr-87/Sr-86 record of Permian seawater. Palaeogeography Palaeoclimatology Palaeoecology, 240, 89 - 107.

LAFUente, B., Downs, R.T., YANG, H., AND StOnE, N. (2015) The power of databases: the RRUFF project. In: Highlights in Mineralogical Crystallography, T. ARMBRUSTER AND R.M. DANISI, eds. Berlin, Germany, W. De Gruyter, pp 1-30 
LARSEN, E.S., KEEVIL, N.B., AND HARRISON, H.C. (1952) Method for determining the age of igneous rocks using the accessory minerals. Bulletin of the Geological Society of America, 63, 1045-1052.

LEWIS, J., COATH, C.D., AND PIKE, A.W.G. (2014) An improved protocol for ${ }^{87} \mathrm{Sr} /{ }^{86} \mathrm{Sr}$ by laser ablation multicollector inductively coupled plasma mass spectrometry using oxide reduction and a customised plasma interface. Chemical Geology, 390, 173-181.

MARAS, A. (1979) Studi sui minerali del Lazio: la kalistrontite di Cesano, Periodico di Mineralogia, 48, 195203.

Markvardsen, A.J., Shankland, K., DAVID, W. I. F., Johnston, J. C., IbBerson, R. M., Tucker, M., NOWELl, H., AND GRIFFIN, T. (2008) ExtSym: a program to aid space-group determination from powder diffraction data. Journal of Applied Crystallography, 41, 1177.

MCARThUR, J.M., HoWARTH, R.J., AND SHIELD, G.A. (2012) Strontium Isotope Stratigraphy. In: F.M.

Gradstein, J.G. Ogg., M.D. Schmitz AND G.M. OgG, Eds., The Geologic Time Scale, 2012, pp. 127-144.

Elsevier, Amsterdam, Netherlands.

MEES, F. (1999) Distribution patterns of gypsum and kalistrontite in a dry lake basin of the southwestern Kalahari (Omongwa pan, Namibia). Earth Surface Processes and Landforms, 24, 731-744.

MIN Mo. (1987) The first discovery of kalistrontite in China and its significance in search for potash deposits. Acta Mineralogica Sinica, 7, 154-158.

MOMMA, K., AND IZUMI, F. (2011) VESTA 3 for three-dimensional visualization of crystal, volumetric and morphology data. Journal of Applied Crystallography, 44, 1272-1276.

Morris, M.C., McMurdie, H.F., Evans, E.H., PARETZKIN, B., DEGroot, J.H., AND NeWberRy, R. (1977) Standard X-ray diffraction powders patterns. Section 14 - Data for 68 substances. National Bureau of Standards (U.S.) Monograph, 25, Sec. 14, p31. 
MU, J., AND PERLMUTTER, D.D. (1981) Thermal decomposition of inorganic sulfates and their hydrates. Industrial \& Engineering Chemistry Process Design and Development, 20, 640-646

NAKAMOTO, K., 2009. Infrared and Raman Spectra of Inorganic and Coordination Compounds Part A: Theory and Applications in Inorganic Chemistry (Sixth edition). John Wiley and Sons, New Jersey.

NELSON, P.H. (2007) Evaluation of potash grade from gamma-ray logs. U.S. Geological Survey Open-File Report 2007-1292.

PALATINUS, L., AND CHAPUIS, G. (2007) SUPERFLIP - a computer program for the solution of crystal structures by charge flipping in arbitrary dimensions. Journal of Applied Crystallography, 40, 786.

PALMER, M.R., AND ELDERFIELD, H. (1985) Sr isotope composition of sea water over the past 75 Myr. Nature, 314(6011), 526-528.

PerYt, T.M., PierRe, C., AND Gryniv, S.P. (1998) Origin of polyhalite deposits in the Zechstein (Upper Permian) Zdrada platform (northern Poland). Sedimentology, 45, 565-578.

Peryt, T.M., Tomassi-Morawiec, H., CZapowski, G., Hryniv, S.P., Pueyo, J.J., Eastoe, C.J., AND Vovnyuk, S. (2005) Polyhalite occurrence in the Werra (Zechstein, Upper Permian) Peribaltic Basin of Poland and Russia: evaporite facies constraints. Carbonates and Evaporites, 20(2), 182-194.

RuffelL, A.H., AND SHelton, R.G. (2000) Permian to Late Triassic postorogenic collapse, early Atlantic rifting, deserts, evaporating seas and mass extinctions. In N. Woodcock and R. Strachan, Eds., Geological History of Britain and Ireland, 297-313. Blackwell: Oxford.

SMITH, D.B. (1995) Marine Permian of England, Geological Conservation Review Series, No. 8, Chapman and Hall, London, 205 pages

SMITH, D.B., AND TAYLOR, J.C.M. (1992) Permian. In J.C.W. COPE, J.K. INGHAM AND P.F. RAWSON, Eds., Atlas of Palaeogeography and Lithofacies, Memoir 13, 87-96. Geological Society, London. 
SMith, D.B., HARWOOD, G.M., PATtISON, J., AND PetTIGREW, T.H. (1986) A revised nomenclature for Upper Permian strata in eastern England. In G.M. HARWOOD AND D.B. SMITH, Eds., The English Zechstein and related topics: Geological Society of London Special Publication no 22.

SMith, F.W., Dearlove, J.P.L., Kemp S.J., BelL, C.P., Milne, C.J., ANd Pottas, T.L. (2014) Potash - recent exploration developments in North Yorkshire. Pp. 45-50 in Proceedings of the 17th Extractive Industry Geology Conference, EIG Conferences Ltd.

STEWART, F.H. (1949) The petrology of the Evaporites of the Eskdale No2 boring. East Yorkshire: I - The Lower Evaporite Bed. Mineralogical Magazine, 28, 621-675.

SteWART, F.H. (1963) The Permian Lower Evaporites of Fordon in Yorkshire. Proceedings of the Yorkshire Geological Society, 34, $1-44$.

STRONG, T.R., AND DRISCOLL, R.L. (2016) A process for reducing rocks and concentrating heavy minerals:

U.S. Geological Survey Open-File Report 2016-1022, 16 p., http://dx.doi.org/10.3133/ofr20161022.

SUn, XIAO-HONG, LIU, CHENG-LIN, JIAO, PENG-CHENG, AND XUAN, ZHI-QIANG. (2013) Sedimentary characteristics of kalistrontite and its significance for potash formation in the Lop Nur Playa, Xinjiang. Acta Mineralogica Sinica, 1000-4734, Issue S1, p 90

SZURLIES, M. (2013) Late Permian (Zechstein) magnetostratigraphy in Western and Central Europe. In A. GĄSIEWICZ AND M. SłOWAKIEWICZ, Eds., Palaeozoic climate cycles: Their evolutionary and sedimentological impact: Geological Society of London Special Publication 376, 73-85,

TISSOT, R.G., RODRIGUEZ, M.A., SIPOLA, D.L., AND VOIGT, J.A. (2001) X-ray powder diffraction study of synthetic Palmierite, $\mathrm{K}_{2} \mathrm{~Pb}\left(\mathrm{SO}_{4}\right)_{2}$. Powder Diffraction, 16, 92-97. 
TUCKER, M.E. (1991) Sequence stratigraphy of carbonate-evaporite basins: models and applications to the Upper Permian (Zechstein) of northeast England and adjoining North Sea. Journal of the Geological Society, London, 148, 1019-1036.

VASSileV, S.V., KItANO, K., TAKedA, S., AND TSURUe, T. (2016) Influence of mineral and chemical composition of coal ashes on their fusibility. Fuel Processing Technology, 45, 27-51.

VEIzER, J. (1989) Strontium Isotopes in Seawater through Time. Annual Review of Earth and Planetary Sciences, 17, 141-167.

VISSER, J.W. (1969) A fully automatic program for finding the unit cell from powder data. Journal of Applied Crystallography, 2, 89.

VoronoVA, M.L. (1962) Kalistrontite, a new potassium strontium sulfate. Zapiski Vsesoyuznogo Mineralogicheskogo Obshchestva, 91, 712-717.

WARBURTON, D.G. (2014) The mechanism of formation of the Zechstein Basin Z2 polyhalite $\left(\mathrm{K}_{2} \mathrm{Ca}_{2} \mathrm{Mg}\left(\mathrm{SO}_{4}\right)_{4} \bullet 2\left(\mathrm{H}_{2} \mathrm{O}\right)\right)$ deposit and its connection to Zechstein Basin evolution. Unpublished MSc. Thesis, University of Leeds.

WARREN, J.K. (2016) Evaporites: A Geological Compendium. Second Edition. Springer.

WEST, R.R., AND SUTTON, W.J. (1953) Thermography of gypsum. Journal of the American Ceramic Society, $37,221-224$.

WOOdHEAD, J., SWEARER, S., HERGT, J., AND MAAS, R. (2005) In situ Sr-isotope analysis of carbonates by LAMC-ICP-MS: interference corrections, high spatial resolution and an example from otolith studies. Journal of Analytical Atomic Spectrometry, 20, 22-27. 


\section{TABLES}

1. North Yorkshire kalistrontite XRD data compared to the ICDD standard (Morris et al., 1977)

2. Crystallographic coordinates extracted from the Rietveld refinement carried out on powder Xray diffraction data using the space group $R \overline{3} m(166)$ at room temperature with cell parameters $\mathrm{a}=\mathrm{b}=5.45826(5) \AA$ and $\mathrm{c}=20.8118(2) \AA$.

3. Chemical analyses (EDX) of kalistrontite compared to previous analyses. Data from the present study represents the mean values for 63 analyses. Analyses from 34 anhydrite sites are included for reference. *analysis recalculated from Voronova (1962) after deduction of included halite and anhydrite. $\mathrm{nd}=$ not detected. SD reported for this study is the variation in the dataset and not the uncertainty in the EDX quantification.

4. Summary of Sr isotope data

\section{FIGURES}

1. Location map indicating the York Potash Ltd area of interest (AOI) and location of the kalistrontite-bearing exploration boreholes, SM6, SM9, SM9A and SM9B (modified from Kemp et al., 2016).

2. Conceptual geological model for the Fordon (Evaporite) Formation in the York Potash Ltd AOI (modified from Kemp et al., 2016) with Permian lithostratigraphical units in N.E. England (after Smith, 1986). The thicknesses of the cover stratigraphical units are the averages of those shown in the kalistrontite-bearing boreholes.

3. Quantitative XRD-derived downhole distribution of kalistrontite and polyhalite (bars) with gamma-ray response (line) in boreholes SM6, SM9, SM9A and SM9B.

4. Photographs of selected intervals of slabbed SM6, SM9, SM9A and SM9B core to illustrate the nature of the deposits and indicate sample (12816-xxxx, 13078-xxxx, 13080-xxxx) and thin 
section positions (SSK6500x). Scale at the top and base of the core boxes is marked in $5 \mathrm{~cm}$ intervals.

5. Rietveld refinement of kalistrontite at room temperature with the symmetry $R \overline{3} m$ (166) using the HighScore Plus suite, version 4.6. The inset shows the fit of the data in the high $2 \theta$ range. Statistics: $\mathrm{R}_{\mathrm{wp}}=1.2, \mathrm{GoF}=2.5$.

6. Crystal structure of kalistrontite (a) standard projection and (b) projected along the $c$ axis. Potassium atoms are represented by purple spheres (omitted in (b) for clarity), strontium atoms and polyhedra are shown in green, sulphur atoms and polyhedra are shown in yellow and oxygen atoms are shown in red. Partial substitution of calcium atoms for strontium is indicated by the blue portions of the green spheres. Unit cell dimensions are shown by black outlines. Images were produced using the program VESTA (Momma and Izumi, 2011).

7. Raman spectrum for kalistrontite (analysis from a mid-range brightness and composition crystal)

8. Thermogravimetric (TGA, black) and accompanying differential thermal analysis (DTA, red) traces together with evolved $\mathrm{SO}_{2}$ mass spectrometer output (blue) for a sample of pure kalistrontite in flowing $\mathrm{N}_{2}$. Note $25^{\circ} \mathrm{C} / \mathrm{min}$ heating rate between ambient and $800^{\circ} \mathrm{C}, 5^{\circ} \mathrm{C} / \mathrm{min}$ heating rate between 800 and $1450^{\circ} \mathrm{C}$.

9. Textural patterns of kalistrontite.

a. Overview of sample SSK65000 (SM6, $1590.81 \mathrm{~m})$; the left part is the whole polished section in plane polarised light (PPL), the right is the same section with BSE imaging. The arrow marks the sample way up. In the BSE image, kalistrontite is the bright phase, a vein of which is labelled (Kal). A halite (HI) vein and the dark anhydrite (Anh) matrix are also marked. The box outlines the area of (c) and (d).

b. PPL photomicrograph showing kalistrontite as the dominant mineral phase in this field of view. There are patches of anhydrite (above centre, lower left, lower right). Textures 
are defined by inclusions whose distribution is independent of the enclosing mineralogy. Several stellate structures are shown along with equant polygonal structures and a discontinuous, notched band. Sample SSK65001 (SM6, 1591.10 m).

c. PPL photomicrograph showing the inclusion-free nature of a kalistrontite vein, with relatively sharp edges defining the transition to the inclusion-rich crystals. Note the inclusion-defined ghost stellate textures in the lower part. Boxed area is site of Fig. 10d. Sample SSK65000 (SM6, $1590.81 \mathrm{~m})$.

d. Cross polarised light (XPL) photomicrograph of the same field of view as (c). Note that a section thickness of $>30 \mu \mathrm{m}$ has generated anomalous birefringence colours. The centre of the kalistrontite vein comprises interlocking dominantly euhedral mm-scale crystals. Above and below this are coarser, poikilotopic, kalistrontite crystals that encompass some of the inclusion-defined textures as well as patches of the anhydrite that forms the bulk of the inclusion-rich material. Sample SSK65000 (SM6, $1590.81 \mathrm{~m}$ ).

10. Textural patterns of kalistrontite.

a. BSE photomicrograph showing coarse poikilotopic kalistrontite (Kal) enclosing rounded and embayed halite (HI) and anhydrite (Anh) as well as euhedral platy magnesite (Mgs). Outside the kalistrontite, halite and anhydrite are intergrown, locally with euhedral contacts, (right), but some halite patches contain multiple rounded and embayed patches of anhydrite (upper right). Sample SSK65000 (SM6, $1590.81 \mathrm{~m}$ ).

b. A high brightness image BSE photomicrograph showing the structure of a magnesite (Mgs) cluster contained within poikilotopic kalistrontite (Kal). Some of the magnesite is well defined as laths relatively free of inclusions (above centre, only containing fine celestine ( $\mathrm{Clt}$ ) blebs), some contains abundant rounded anhydrite (Anh; lower left). There are euhedral enclosures of anhydrite and halite $(\mathrm{HI})$. However, the outer margins 
of the cluster are uneven and embayed by the kalistrontite, which itself contains common rounded blebs of anhydrite (upper left, top). Sample SSK65001 (SM6, $1591.10 \mathrm{~m})$.

c. A contrast-boosted BSE photomicrograph from the centre of a kalistrontite vein with a texture dominated by euhedral, interlocking $\mathrm{mm}$ - and sub-mm-scale crystals. Brightness variations correlate to compositional variation with darker portions having higher $\mathrm{Ca}$ contents (see Fig. 12). Although some crystal cores show a blocky pattern of brightness variation, the most consistent pattern is for crystals to be darkest at edges, suggesting last formed kalistrontite has the highest Ca content. Sample SSK65001 (SM6, $1591.10 \mathrm{~m})$.

d. BSE photomicrograph showing the area outlined in Fig. 9c. Kalistrontite (Kal) is the brighter phase. The contact with darker anhydrite (Anh) is irregular. Fine blebs of anhydrite are enclosed by the kalistrontite adjacent to the contact. Anhydrite is largely inclusion-rich; magnesite (Mgs) plates are typically associated with inclusions. One anhydrite crystal (marked Anh*) is inclusion-free and has a euhedral contact with kalistrontite. Sample SSK65000 (SM6, $1590.81 \mathrm{~m})$.

e. A contrast-boosted BSE photomicrograph showing several bladed polyhalite (Phal) crystals in a matrix of anhydrite (Anh) showing backscatter coefficient variation. In the crystal to left of centre this shows as concentric zones with the bright centre having a higher content of $\mathrm{Sr}$ than the darker margins. Both magnesite (Mgs) and irregular anhydrite are enclosed by the polyhalite. Polyhalite cuts through a halite (HI) kalistrontite (Kal) patch in which the latter is present as irregular, rounded and embayed forms all of which have common extinction under optical XPL. Halite-anhydrite contacts 
are jagged except where there are euhedral anhydrite (Anh*) crystals in the halite that cut across kalistrontite. Sample SSK65002 (SM6, 1587.29 m).

f. PPL optical photomicrograph of the same area as (e). The nodular, enterolithic inclusion pattern bridges the polyhalite-anhydrite contact, suggesting both phases have formed replacing primary deposit constituents. Sample SSK65002 (SM6, 1587.29 m) OM

11. Laser ablation Sr isotopic data for the kalistrontite and anhydrite in samples SK65000 and SK65001 compared to dissolution values obtained for the North Yorkshire polyhalite and anhydrite (Warburton, 2014). Mean values are indicated by the dashed lines. The shaded box represents a range of values for Permian seawater (Korte et al., 2006; Kani et al., 2013).

12. Plot of North Yorkshire kalistrontite EDX-derived atomic \% data of Ca content versus Sr content. Error bars are $1 x$ quantification SD. A value for end-member, stoichiometric kalistrontite is shown as an end point to the theoretical Ca-Sr mixing line. The data has a trend that runs parallel to the theoretical line, showing that the Sr compositional variation is a result of $\mathrm{Ca}$ substitution. The trend is consistently below the ideal line, but within $2 x$ quantification SD. Where possible, data has been labelled for darker and brighter BSE imaging characteristics, showing that darker kalistrontite is enriched in Ca and depleted in Sr. 


\section{SUPPLEMENTARY TABLES}

1. Summary of quantitative XRD analyses of kalistrontite-bearing samples from boreholes SM6, SM9, SM9A and SM9B. (nd: not detected).

2. Metadata for $\mathrm{Sr}$ isotope analyses

3. Sample and validation data from $\mathrm{Sr}$ isotope analyses

4. Summary of EDX microanalysis for kalistrontite and anhydrite from North Yorkshire

\section{SUPPLEMENTARY FIGURES}

1. Comparison of North Yorkshire kalistrontite geochemistry with analyses for previous occurrences. SD for the North Yorkshire data shown by the whisker plot.

2. Plot of North Yorkshire kalistrontite EDX-derived weight $\%$ data, showing the ratio of $K$ to $S$ (X axis) plotted against the ratio of $\mathrm{Sr}$ to $\mathrm{S}(\mathrm{Y}$ axis). Error bars are $1 \mathrm{x}$ quantification $\mathrm{SD}$. The $\mathrm{K} / \mathrm{S}$ ratio shows no particular trend and is within quantification error of the end-member, stoichiometric kalistrontite value. The Sr/S values are all significantly below and forming a clear trend, independent of the $\mathrm{K} / \mathrm{S}$ ratio, away from that expected of end member kalistrontite.

\section{SUPPLEMENTARY FILES}

1. Kalistrontite CIF 
Table 1. Kalistrontite XRD data compared to ICDD standard (Morris et al., 1977)

\begin{tabular}{|c|c|c|c|c|c|c|c|c|c|c|}
\hline \multicolumn{3}{|c|}{ Miller index } & \multicolumn{3}{|c|}{ ICDD, 00-029-1049 } & \multicolumn{3}{|c|}{ This study } & \multicolumn{2}{|c|}{ Differential } \\
\hline $\mathrm{h}$ & k & 1 & $\begin{array}{c}{ }^{\circ} 2 \theta \\
(\mathrm{Mo}-\mathrm{K} \alpha)\end{array}$ & $d(\AA ̊)$ & $\begin{array}{l}\text { Rel. int. } \\
\text { (\%) }\end{array}$ & $\begin{array}{c}{ }^{\circ} 2 \theta \\
(\mathrm{Mo}-\mathrm{K} \alpha)\end{array}$ & $d(\AA ̊)$ & $\begin{array}{l}\text { Rel. int. } \\
\text { (\%) }\end{array}$ & $d(\AA ̊)$ & $\begin{array}{l}\text { Rel. int. } \\
\text { (\%) }\end{array}$ \\
\hline$\overline{0}$ & 0 & 3 & 5.8584 & 6.940 & 15 & 5.8598 & 6.93863 & 14.46 & 0.00137 & 0.54 \\
\hline 1 & 0 & 1 & 8.8109 & 4.617 & 1 & 8.8241 & 4.61025 & 0.82 & 0.00675 & 0.18 \\
\hline 0 & 1 & 2 & 9.4443 & 4.308 & 17 & 9.4525 & 4.30436 & 13.08 & 0.00364 & 3.92 \\
\hline 1 & 0 & 4 & & & & 11.6345 & 3.49915 & 0.59 & & \\
\hline 0 & 0 & 6 & 11.7255 & 3.472 & 1 & 11.7356 & 3.46912 & 0.43 & 0.00288 & 0.57 \\
\hline 0 & 1 & 5 & 13.0203 & 3.128 & 100 & 13.0362 & 3.12429 & 100.00 & 0.00371 & 0.00 \\
\hline 1 & 1 & 0 & 14.9231 & 2.731 & 65 & 14.9321 & 2.72944 & 67.60 & 0.00156 & -2.60 \\
\hline 1 & 1 & 3 & 16.0333 & 2.543 & 11 & 16.0531 & 2.53996 & 10.12 & 0.00304 & 0.88 \\
\hline 1 & 0 & 7 & 16.1807 & 2.520 & 4 & 16.2005 & 2.51701 & 2.77 & 0.00299 & 1.23 \\
\hline 0 & 2 & 1 & 17.3450 & 2.352 & 2 & 17.3704 & 2.34865 & 1.08 & 0.00335 & 0.92 \\
\hline 0 & 0 & 9 & 17.6168 & 2.316 & 8 & 17.6425 & 2.31271 & 6.84 & 0.00329 & 1.16 \\
\hline 2 & 0 & 2 & 17.6783 & 2.308 & 6 & 17.7017 & 2.30504 & 3.77 & 0.00296 & 2.23 \\
\hline 1 & 0 & 8 & & & & 17.9025 & 2.27939 & 0.38 & & \\
\hline 0 & 2 & 4 & 18.9624 & 2.153 & 17 & 18.9708 & 2.15211 & 10.97 & 0.00089 & 6.03 \\
\hline 1 & 1 & 6 & 19.0069 & 2.148 & 19 & 19.0337 & 2.14507 & 13.96 & 0.00293 & 5.04 \\
\hline 2 & 0 & 5 & 19.8502 & 2.0576 & 25 & 19.8714 & 2.05549 & 27.74 & 0.00211 & -2.74 \\
\hline 1 & 0 & 10 & 21.4277 & 1.9077 & 18 & 21.4595 & 1.90496 & 24.10 & 0.00274 & -6.10 \\
\hline 2 & 1 & 1 & 22.9617 & 1.7818 & 3 & 22.9824 & 1.78026 & 2.26 & 0.00154 & 0.74 \\
\hline 1 & 1 & 9 & 23.1646 & 1.7664 & 5 & 23.1912 & 1.76445 & 4.04 & 0.00195 & 0.96 \\
\hline 1 & 2 & 2 & 23.2206 & 1.7622 & 2 & 23.2367 & 1.76104 & 1.01 & 0.00116 & 0.99 \\
\hline 1 & 0 & 11 & & & & 23.2949 & 1.75671 & 0.29 & & \\
\hline 2 & 0 & 8 & 23.3631 & 1.7516 & 3 & 23.3918 & 1.74952 & 2.65 & 0.00208 & 0.35 \\
\hline 0 & 0 & 12 & 23.5705 & 1.7364 & 3 & 23.5972 & 1.73451 & 2.28 & 0.00189 & 0.72 \\
\hline 2 & 1 & 4 & 24.2056 & 1.6915 & $<1$ & 24.2287 & 1.68995 & 0.02 & 0.00155 & $n / a$ \\
\hline 1 & 2 & 5 & 24.9237 & 1.6435 & 12 & 24.9484 & 1.64194 & 13.47 & 0.00156 & -1.47 \\
\hline 3 & 0 & 0 & 25.9894 & 1.5772 & 7 & 26.0133 & 1.57581 & 8.05 & 0.00139 & -1.05 \\
\hline 0 & 2 & 10 & 26.2109 & 1.5641 & 5 & 26.2457 & 1.56210 & 4.45 & 0.00200 & 0.55 \\
\hline 3 & 0 & 3 & 26.6709 & 1.5376 & 2 & 26.6880 & 1.53667 & 0.84 & 0.00093 & 1.16 \\
\hline 2 & 1 & 7 & & & & 26.7790 & 1.53155 & 0.13 & & \\
\hline 2 & 0 & 11 & & & & 27.7840 & 1.47718 & 0.01 & & \\
\hline 2 & 1 & 8 & & & & 27.8663 & 1.47290 & 0.05 & & \\
\hline 1 & 1 & 12 & 28.0052 & 1.4657 & 1 & 28.0409 & 1.46391 & 0.82 & 0.00179 & 0.18 \\
\hline 3 & 0 & 6 & 28.6007 & 1.4358 & 2 & 28.6235 & 1.43472 & 1.05 & 0.00108 & 0.95 \\
\hline 0 & 1 & 14 & 28.9238 & 1.4201 & 1 & 28.9634 & 1.41824 & 0.84 & 0.00186 & 0.16 \\
\hline 0 & 0 & 15 & 29.5816 & 1.3892 & 2 & 29.6173 & 1.3876 & 2.09 & 0.00160 & -0.09 \\
\hline 2 & 2 & 0 & 30.1071 & 1.3655 & 8 & 30.1262 & 1.36469 & 8.88 & 0.00081 & -0.88 \\
\hline 2 & 1 & 10 & 30.3002 & 1.3570 & 9 & 30.3295 & 1.35576 & 12.09 & 0.00124 & -3.09 \\
\hline 2 & 2 & 3 & 30.6940 & 1.3400 & 1 & 30.7176 & 1.33903 & 0.55 & 0.00097 & 0.45 \\
\hline 0 & 2 & 13 & 30.9950 & 1.3273 & 1 & 31.0366 & 1.3256 & 0.61 & 0.00170 & 0.39 \\
\hline 3 & 1 & 1 & & & & 31.4513 & 1.30856 & 0.07 & & \\
\hline 3 & 0 & 9 & 31.5806 & 1.3033 & 1 & 31.6078 & 1.30224 & 0.49 & 0.00106 & 0.51 \\
\hline 3 & 1 & 2 & & & & 31.6421 & 1.30087 & 0.06 & & \\
\hline 1 & 2 & 11 & 31.6453 & 1.3007 & 2 & 31.6858 & 1.29911 & 0.62 & 0.00159 & 1.38 \\
\hline 1 & 3 & 4 & 32.3709 & 1.2723 & $<1$ & 32.3951 & 1.27141 & 0.17 & 0.00089 & $n / a$ \\
\hline 2 & 0 & 14 & & & & 32.7373 & 1.25848 & 0.01 & & \\
\hline 1 & 0 & 16 & & & & 32.8506 & 1.25425 & 0.56 & & \\
\hline 3 & 1 & 5 & 32.9295 & 1.2513 & 5 & 32.9498 & 1.25058 & 5.41 & 0.00072 & -0.41 \\
\hline 1 & 1 & 15 & 33.2824 & 1.2384 & 8 & 33.3242 & 1.23693 & 10.00 & 0.00147 & -2.00 \\
\hline
\end{tabular}


Revision 1

\begin{tabular}{|c|c|c|c|c|r|c|c|c|c|c|}
\hline 1 & 3 & 7 & 34.3564 & 1.2008 & $<1$ & 34.3901 & 1.19969 & 0.11 & 0.00111 & $\mathrm{n} / \mathrm{a}$ \\
\hline 2 & 1 & 13 & & & & 34.6069 & 1.19240 & 0.06 & & \\
\hline 2 & 2 & 9 & 35.0888 & 1.1765 & 1 & 35.1264 & 1.17531 & 0.75 & 0.00119 & 0.25 \\
\hline 4 & 0 & 2 & & & & 35.1576 & 1.17430 & 0.07 & & \\
\hline 3 & 0 & 12 & 35.3619 & 1.1677 & $<1$ & 35.4056 & 1.16634 & 0.06 & 0.00136 & $\mathrm{n} / \mathrm{a}$ \\
\hline 4 & 0 & 4 & 35.8183 & 1.1533 & $<1$ & 35.8451 & 1.15250 & 0.19 & 0.00080 & $\mathrm{n} / \mathrm{a}$ \\
\hline 1 & 2 & 14 & 36.1162 & 1.1441 & 1 & 36.1584 & 1.14284 & 0.17 & 0.00126 & 0.83 \\
\hline 0 & 2 & 16 & 36.2178 & 1.1410 & 1 & 36.2623 & 1.13967 & 0.29 & 0.00133 & 0.71 \\
\hline 0 & 4 & 5 & 36.3199 & 1.1379 & 2 & 36.3533 & 1.13692 & 1.76 & 0.00098 & 0.24 \\
\hline 1 & 3 & 10 & 37.2485 & 1.1105 & 3 & 37.2885 & 1.10938 & 3.41 & 0.00112 & -0.41 \\
\hline 2 & 0 & 17 & & & & 38.0797 & 1.08716 & 0.11 & & \\
\hline 3 & 2 & 2 & & & & 38.3901 & 1.07870 & 0.19 & & \\
\hline 4 & 0 & 8 & & & & 38.4888 & 1.07603 & 0.17 & & \\
\hline 2 & 2 & 12 & 38.5747 & 1.0737 & 1 & 38.6202 & 1.07251 & 0.62 & 0.00119 & 0.38 \\
\hline 1 & 0 & 19 & & & & 38.8205 & 1.06719 & 0.28 & & \\
\hline 1 & 1 & 18 & 38.8607 & 1.0661 & 1 & 38.9143 & 1.06472 & 0.41 & 0.00138 & 0.59 \\
\hline 2 & 1 & 16 & & & & 39.4169 & 1.05167 & 0.27 & & \\
\hline 2 & 3 & 5 & 39.4577 & 1.0506 & 3 & 39.5016 & 1.04951 & 2.83 & 0.00109 & 0.17 \\
\hline 3 & 0 & 15 & 39.7731 & 1.0426 & 4 & 39.8223 & 1.04139 & 2.00 & 0.00121 & 2.00 \\
\hline 4 & 1 & 0 & 40.1829 & 1.0324 & 2 & 40.2165 & 1.03160 & 2.19 & 0.00080 & -0.19 \\
\hline 4 & 0 & 10 & 40.3337 & 1.0287 & 1 & 40.3747 & 1.02773 & 0.77 & 0.00097 & 0.23 \\
\hline 4 & 1 & 3 & 40.6513 & 1.0210 & 1 & 40.6781 & 1.02038 & 0.14 & 0.00062 & 0.86 \\
\hline 3 & 2 & 7 & & & & 40.7408 & 1.01888 & 0.17 & & \\
\hline 0 & 1 & 20 & 40.7764 & 1.0180 & 1 & 40.8463 & 1.01636 & 1.23 & 0.00164 & -0.23 \\
\hline
\end{tabular}

n/a not available 
Table 2. Crystallographic coordinates extracted from the Rietveld refinement carried out on powder X-ray diffraction data using the space group $R \overline{3} m(166)$ at room temperature with cell parameters $\mathrm{a}=\mathrm{b}=5.45826(5) \AA$ and $\mathrm{c}=$ $20.8118(2) \AA$.

\begin{tabular}{|c|c|c|c|c|c|c|}
\hline Atom & $\begin{array}{c}\text { Wyckoff } \\
\text { site }\end{array}$ & $\begin{array}{c}\text { Site } \\
\text { occupancy } \\
\text { factor }\end{array}$ & $\mathbf{x}$ & $\mathbf{y}$ & $\mathbf{z}$ & $\mathbf{B}_{\text {iso }}\left(\mathbf{1 0}^{\mathbf{4}} \mathbf{p m}^{\mathbf{2}}\right)$ \\
\hline $\mathrm{Sr} 1$ & $3 \mathrm{a}$ & $0.893(5)$ & $1 / 3$ & $2 / 3$ & $2 / 3$ & $1.67(2)$ \\
\hline $\mathrm{Ca}$ & $3 \mathrm{a}$ & $0.107(5)$ & $1 / 3$ & $2 / 3$ & $2 / 3$ & $1.67(2)$ \\
\hline $\mathrm{K} 1$ & $6 \mathrm{c}$ & 1.00000 & $2 / 3$ & $1 / 3$ & $0.53411(6)$ & $1.11(2)$ \\
\hline $\mathrm{S} 1$ & $6 \mathrm{c}$ & 1.00000 & 0 & 0 & $0.59941(7)$ & $0.46(2)$ \\
\hline $\mathrm{O} 1$ & $18 \mathrm{~h}$ & 1.00000 & $0.1852(2)$ & $0.8148(2)$ & $0.09278(6)$ & $1.15(3)$ \\
\hline $\mathrm{O} 2$ & $6 \mathrm{c}$ & 1.00000 & $2 / 3$ & $1 / 3$ & $0.6647(1)$ & $1.25(4)$ \\
\hline
\end{tabular}


Table 3. Geochemical analyses (EDX) of kalistrontite compared to previous analyses. Data from the present study represents the mean values for 63 analyses. Analyses from 34 anhydrite sites from the present study are included for reference. ${ }^{*}$ analysis recalculated from Voronova (1962) after deduction of included halite and anhydrite. nd $=$ not detected. SD reported for this study is the variation in the dataset and not the uncertainty in the EDX quantification.

\begin{tabular}{|c|c|c|c|c|c|c|}
\hline & \multicolumn{2}{|c|}{ Alshtan, Russia } & \multirow{2}{*}{$\begin{array}{c}\text { Pleismar, } \\
\text { Germany } \\
\text { Bader \& } \\
\text { Bohm } \\
(1966)\end{array}$} & \multirow{2}{*}{\begin{tabular}{|c|}
$\begin{array}{c}\text { Stoichiometric } \\
\mathrm{K}_{2} \mathrm{Sr}\left(\mathrm{SO}_{4}\right)_{2}\end{array}$ \\
$\begin{array}{c}\text { Morris et al. } \\
(1977)\end{array}$
\end{tabular}} & \multicolumn{2}{|c|}{ N. Yorkshire, UK; this study } \\
\hline & $\begin{array}{l}\text { Voronova } \\
\text { (1962) }\end{array}$ & $\begin{array}{c}\text { Fleischer } \\
(1963)^{*}\end{array}$ & & & $\begin{array}{l}\text { Kalistrontite } \\
\text { (SD) }\end{array}$ & $\begin{array}{l}\text { Anhydrite } \\
\text { (SD) }\end{array}$ \\
\hline $\mathrm{SO}_{3}$ & 45.45 & 47.73 & 43.72 & 44.73 & $45.49(0.39)$ & $58.86(0.49$ \\
\hline $\mathrm{R}_{2} \mathrm{O}_{3}$ & 0.02 & - & - & - & nd & nd \\
\hline $\mathrm{MgO}$ & 0.13 & 0.14 & 0.34 & - & $0.01(0.03)$ & $0.02(0.08)$ \\
\hline $\mathrm{CaO}$ & 5.15 & 5.41 & 3.99 & - & $1.30(0.27)$ & $40.44(0.34)$ \\
\hline $\mathrm{SrO}$ & 23.20 & 24.35 & 25.08 & 28.95 & $26.75(0.52)$ & $0.44(0.16)$ \\
\hline $\mathrm{Na}_{2} \mathrm{O}$ & 4.15 & 2.18 & 1.50 & - & $0.05(0.08)$ & $0.03(0.07)$ \\
\hline $\mathrm{K}_{2} \mathrm{O}$ & 19.22 & 20.19 & 22.22 & 26.32 & $26.95(0.24)$ & $0.03(0.07)$ \\
\hline $\mathrm{Cl}$ & 1.56 & - & 1.72 & - & nd & nd \\
\hline $\mathrm{H}_{2} \mathrm{O}$ & 0.90 & - & 0.28 & - & nd & - \\
\hline insol. & 0.07 & - & 0.63 & - & nd & - \\
\hline$-\mathrm{O}=\mathrm{Cl}_{2}$ & 0.35 & - & 0.14 & - & nd & - \\
\hline Total & 99.50 & {$[100.00]$} & 99.34 & 100.00 & 100.55 & 99.81 \\
\hline \multicolumn{7}{|c|}{ Number of ions on the basis of $8(0)$ for kalistrontite, $4(0)$ for anhydrite } \\
\hline $\mathrm{SO}_{4}$ & 1.94 & 2.01 & 1.95 & 2.00 & 2.00 & 1.00 \\
\hline R & 0.00 & - & - & - & - & - \\
\hline $\mathrm{Mg}$ & 0.01 & 0.01 & 0.03 & - & 0.00 & 0.00 \\
\hline $\mathrm{Ca}$ & 0.31 & 0.33 & 0.25 & - & 0.08 & 0.98 \\
\hline $\mathrm{Sr}$ & 0.76 & 0.79 & 0.87 & 1.00 & 0.91 & 0.01 \\
\hline $\mathrm{Na}$ & 0.46 & 0.24 & 0.17 & - & 0.01 & 0.00 \\
\hline $\mathrm{K}$ & 1.39 & 1.45 & 1.69 & 2.00 & 2.01 & 0.00 \\
\hline $\mathrm{H}_{2} \mathrm{O}$ & 0.34 & - & 0.11 & - & - & - \\
\hline Total & 5.22 & 4.82 & 5.08 & 5.00 & 5.01 & 2.00 \\
\hline
\end{tabular}


Table 4. Summary of Sr isotope data

\begin{tabular}{|c|c|c|c|c|c|c|c|}
\hline Borehole & Depth (m) & Thin section & Mineral & $\begin{array}{c}\text { No. } \\
\text { analyses }\end{array}$ & ${ }^{87} \mathrm{Sr} /{ }^{86} \mathrm{Sr}$ & 2SE & MSWD \\
\hline \multirow{4}{*}{ SM6 } & \multirow{2}{*}{1590.81} & \multirow{2}{*}{ SSK65000 } & Kalistrontite & 10 & 0.707020 & 0.000014 & 1.3 \\
\hline & & & Anhydrite & 2 & 0.707042 & (average of 2) & $\mathrm{n} / \mathrm{a}$ \\
\hline & \multirow{2}{*}{1591.10} & \multirow{2}{*}{ SSK65001 } & Kalistrontite & 8 & 0.707005 & 0.000010 & 0.39 \\
\hline & & & Anhydrite & 5 & 0.707031 & 0.000017 & 0.69 \\
\hline \multicolumn{4}{|c|}{ NBS987 standard $\mathrm{SrCO}_{3},{ }^{87} \mathrm{Sr} /{ }^{86} \mathrm{Sr}=0.71025$} & 4 & $0.710272^{*}$ & 0.000018 & $\mathrm{n} / \mathrm{a}$ \\
\hline \multicolumn{4}{|c|}{ Modern marine mollusc shell } & 7 & 0.709192 & 0.000020 & 1.1 \\
\hline \multicolumn{4}{|c|}{ Kalistrontite combined } & 18 & 0.707014 & 0.000010 & 0.96 \\
\hline \multicolumn{4}{|c|}{ Anhydrite combined } & 7 & 0.707033 & 0.000017 & 0.75 \\
\hline
\end{tabular}

*value not normalised to NBS987 
This is a preprint, the final version is subject to change, of the American Mineralogist (MSA)

Cite as Authors (Year) Title. American Mineralogist, in press.

DOI: https://doi.org/10.2138/am-2018-6194

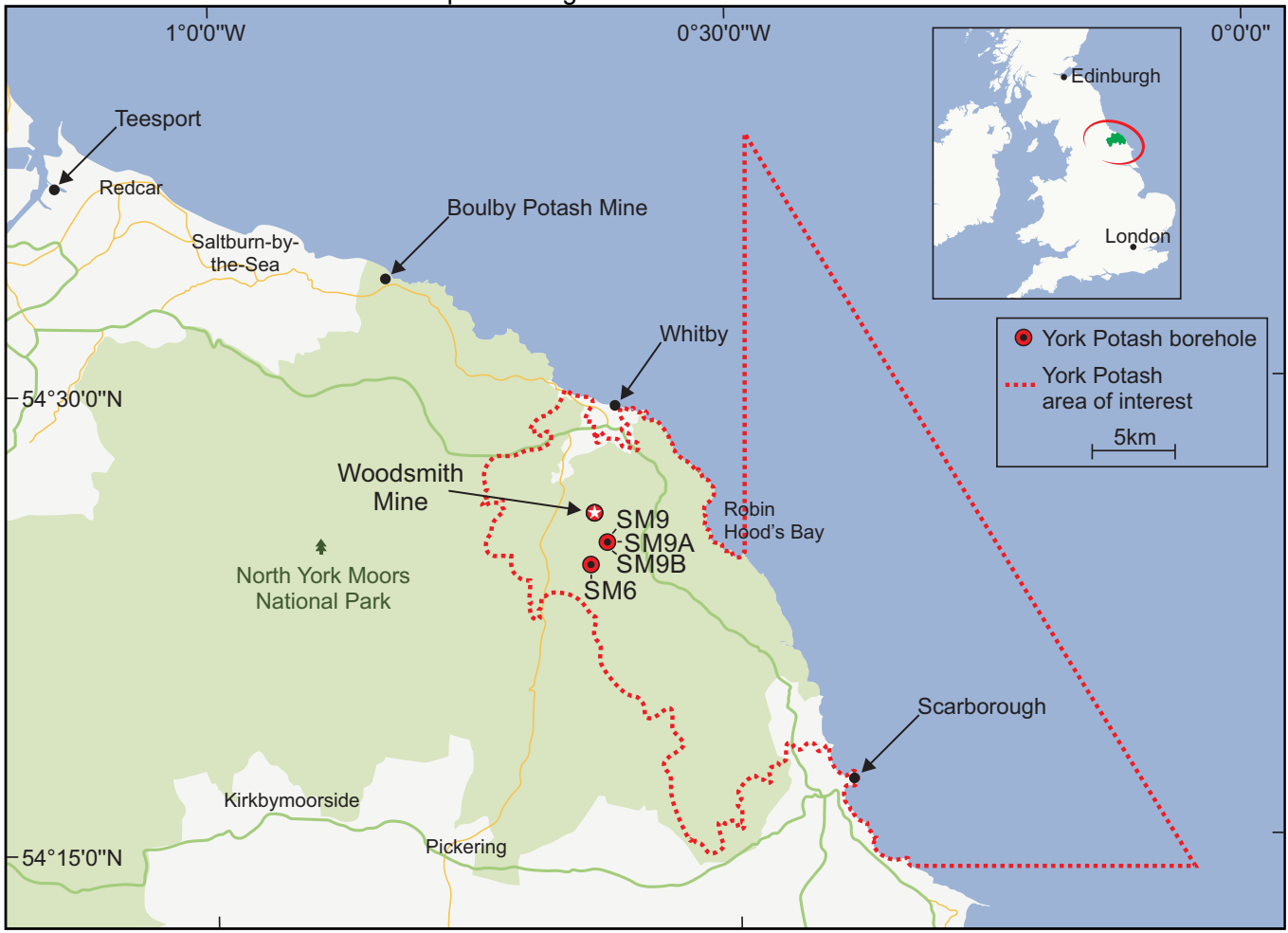

\section{Figure 1}

Always consult and cite the final, published document. See http:/www.minsocam.org or GeoscienceWorld 
This is a preprint, the final version is subject to change, of the American Mineralogist (MSA) Cite as Authors (Year) Title. American Mineralogist, in press.

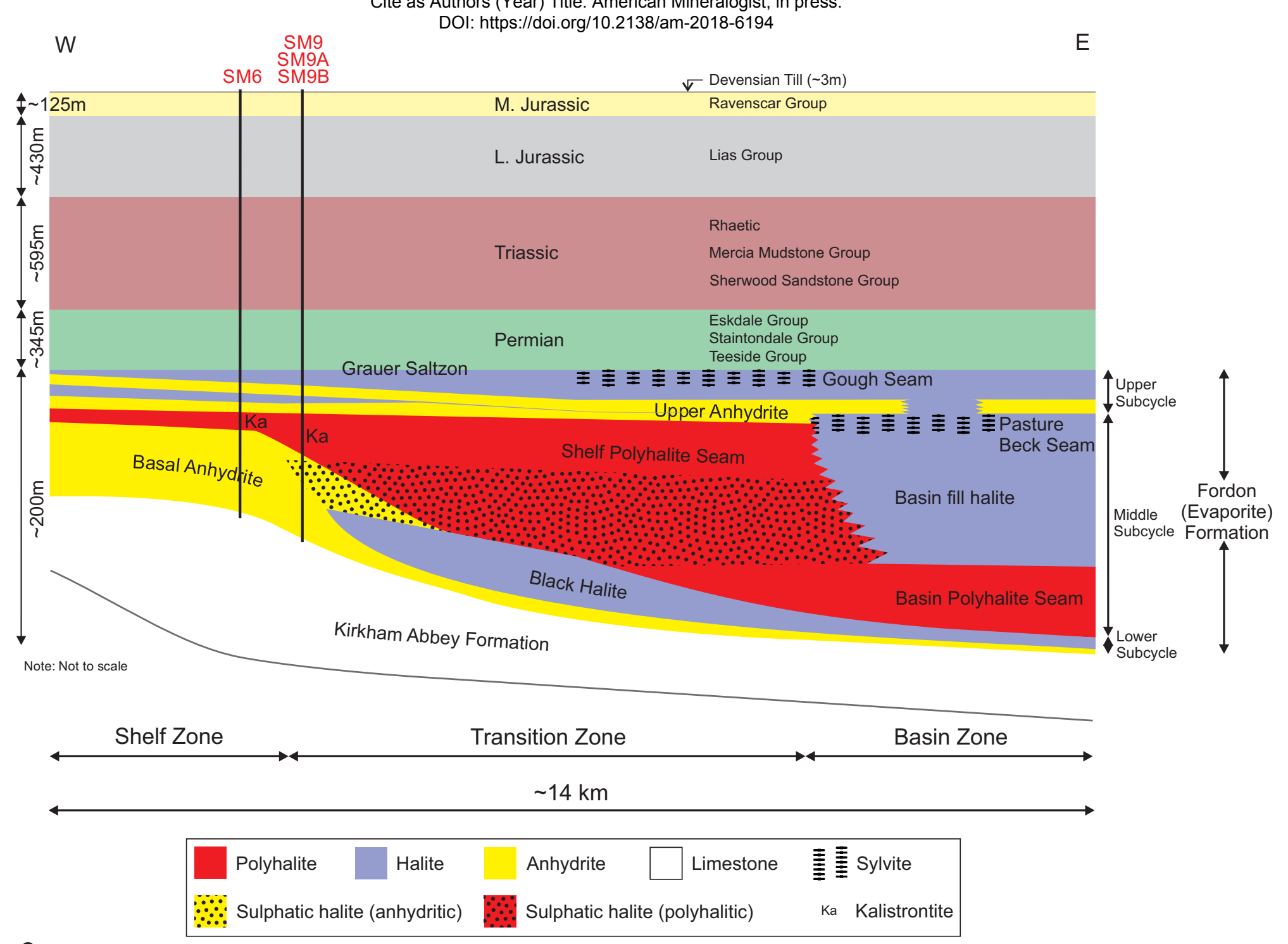

Figure 2

Always consult and cite the final, published document. See http:/www.minsocam.org or GeoscienceWorld 


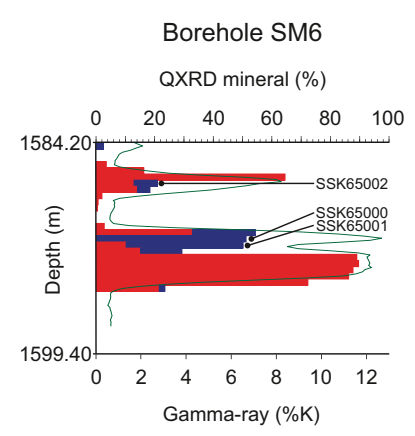

(a)
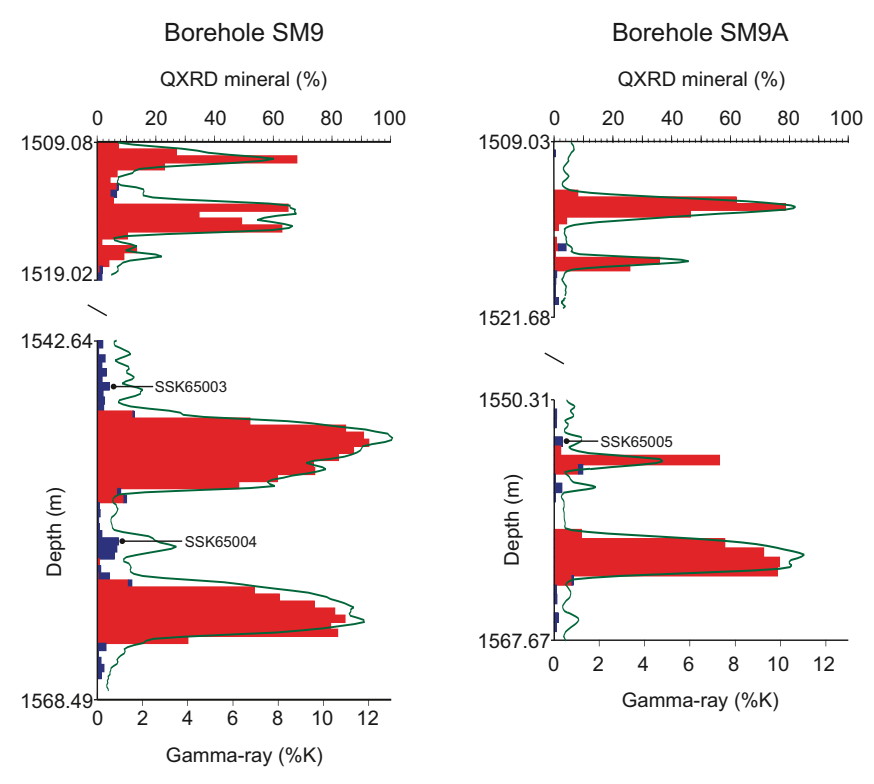

(b)

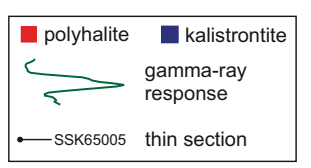

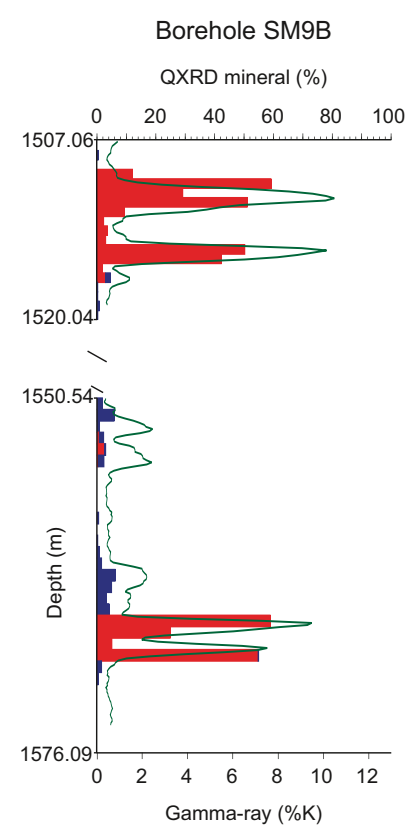

(d)

Figure 3 
This is a preprint, the final version is subject to change, of the American Mineralogist (MSA) Cite as Authors (Year) Title. American Mineralogist, in press.
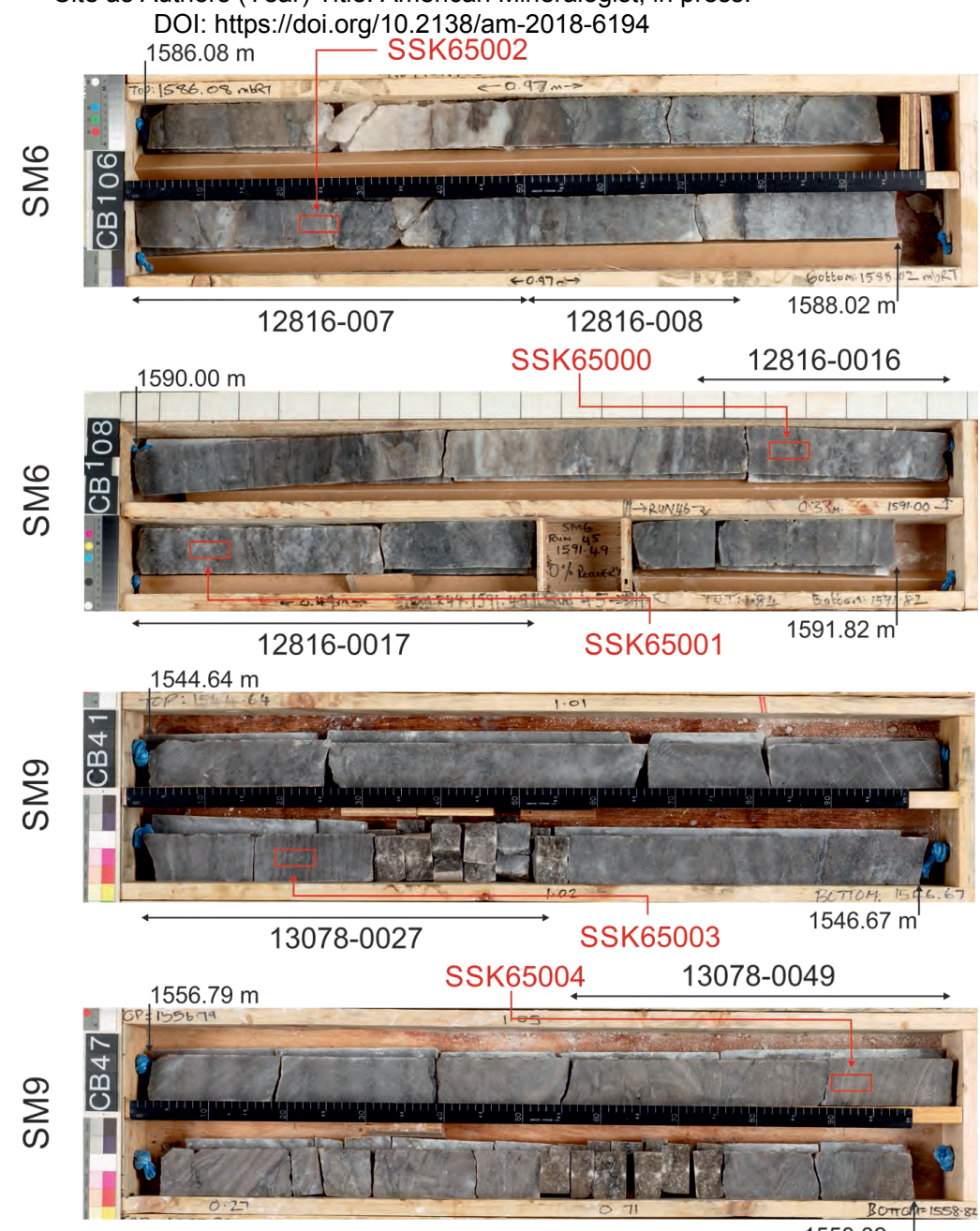

$1558.82 \mathrm{~m}$

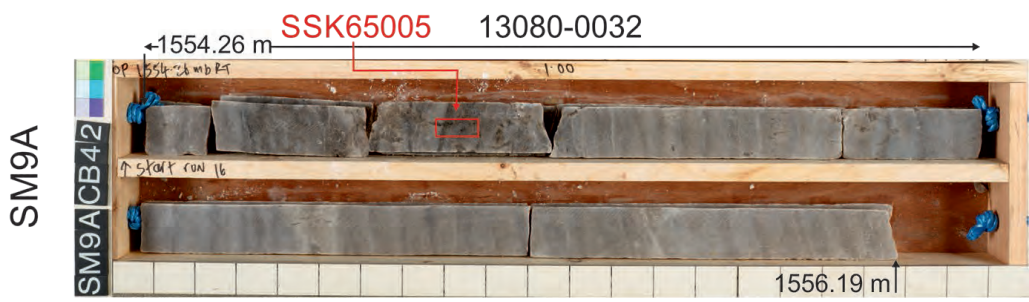

Figure 4

Always consult and cite the final, published document. See http:/www.minsocam.org or GeoscienceWorld 
This is a preprint, the final version is subject to change, of the American Mineralogist (MSA) Cite as Authors (Year) Title. American Mineralogist, in press.

DOI: https://doi.org/10.2138/am-2018-6194

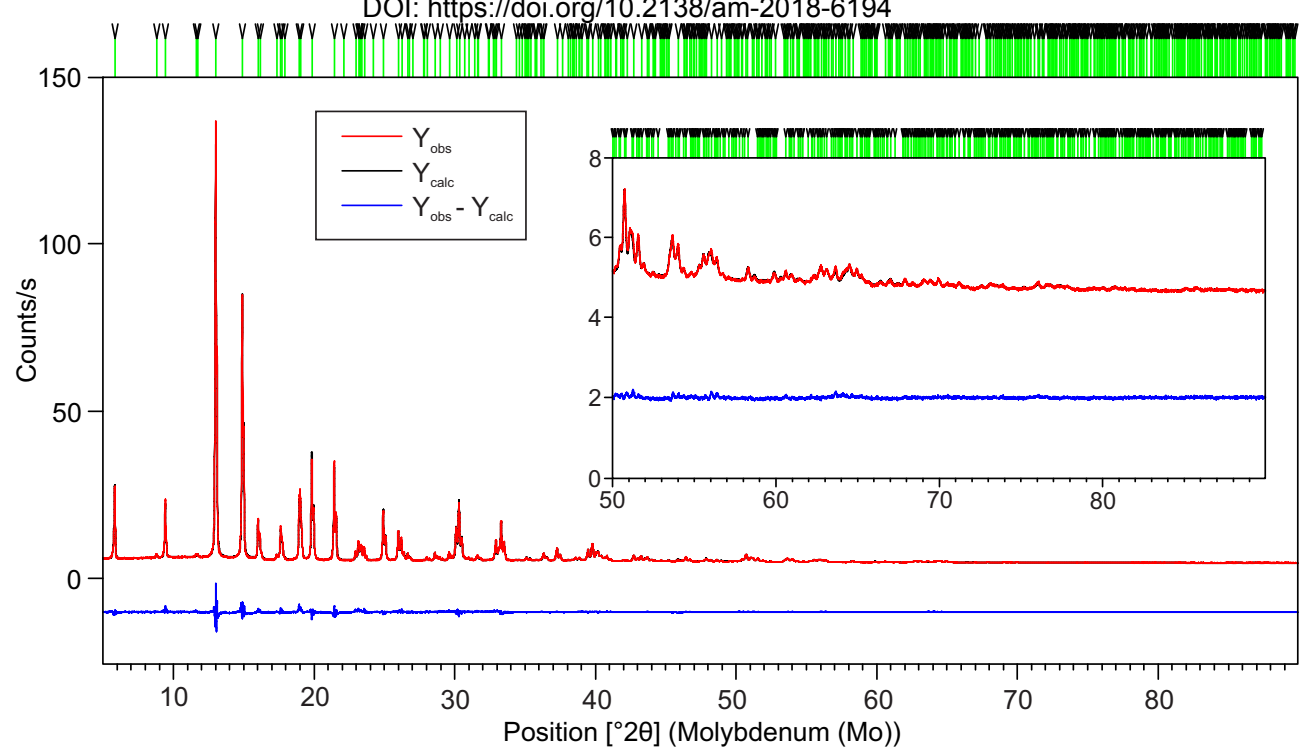

\section{Figure 5}

Always consult and cite the final, published document. See http:/www.minsocam.org or GeoscienceWorld 
This is a preprint, the final version is subject to change, of the American Mineralogist (MSA) Cite as Authors (Year) Title. American Mineralogist, in press. DOI: https://doi.org/10.2138/am-2018-6194

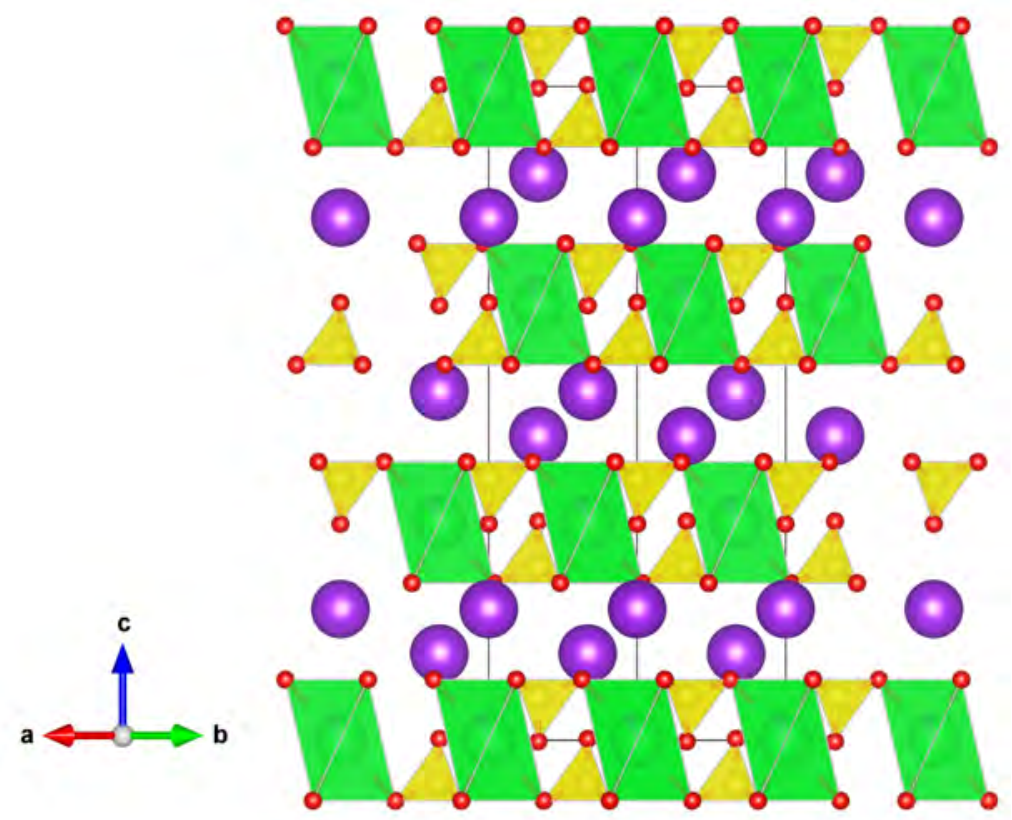

(a)

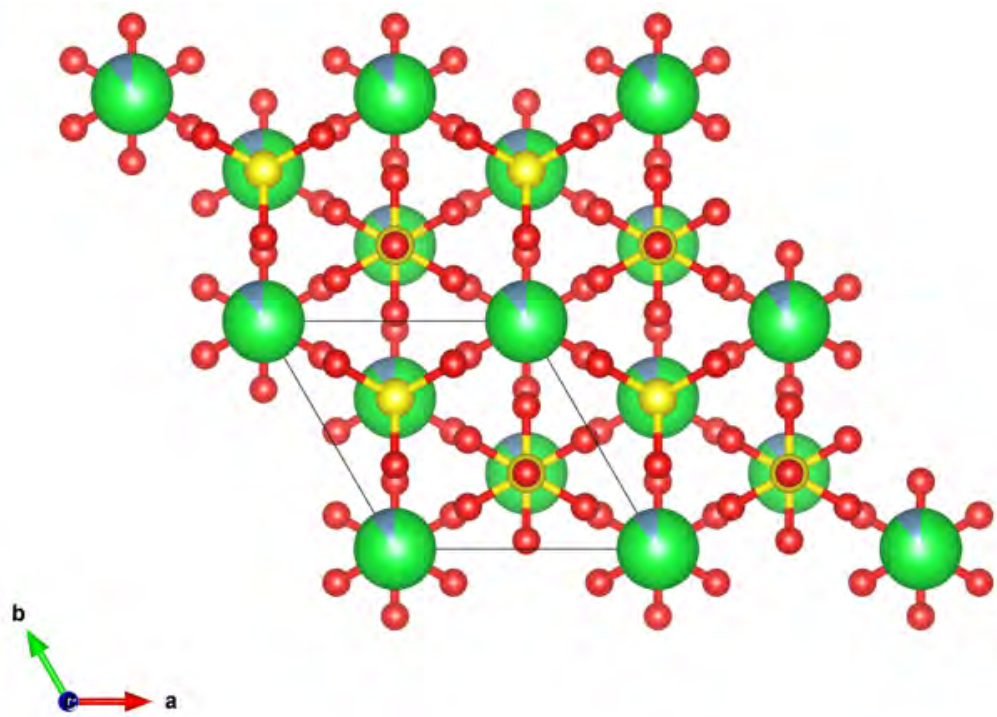

(b)

Figure 6 
This is a preprint, the final version is subject to change, of the American Mineralogist (MSA)

Cite as Authors (Year) Title. American Mineralogist, in press.

DOI: https://doi.org/10.2138/am-2018-6194

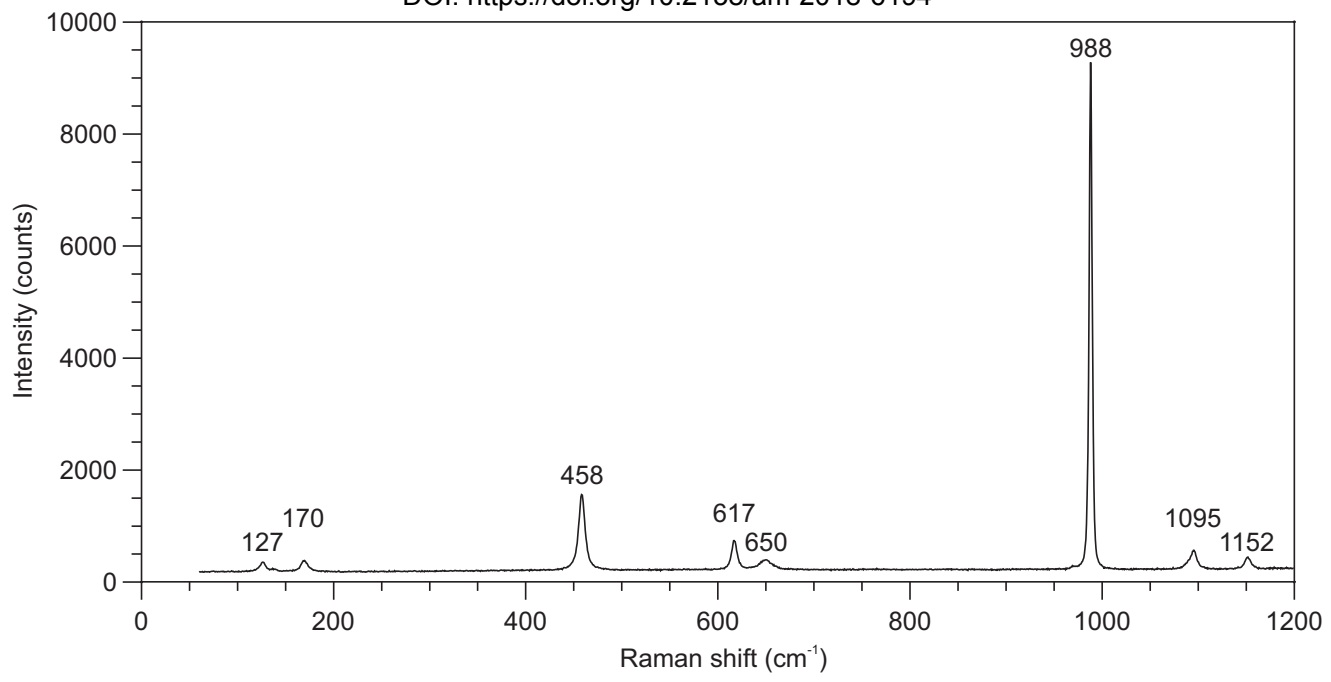

Figure 7

Always consult and cite the final, published document. See http:/www.minsocam.org or GeoscienceWorld 
This is a preprint, the final version is subject to change, of the American Mineralogist (MSA)

Cite as Authors (Year) Title. American Mineralogist, in press.

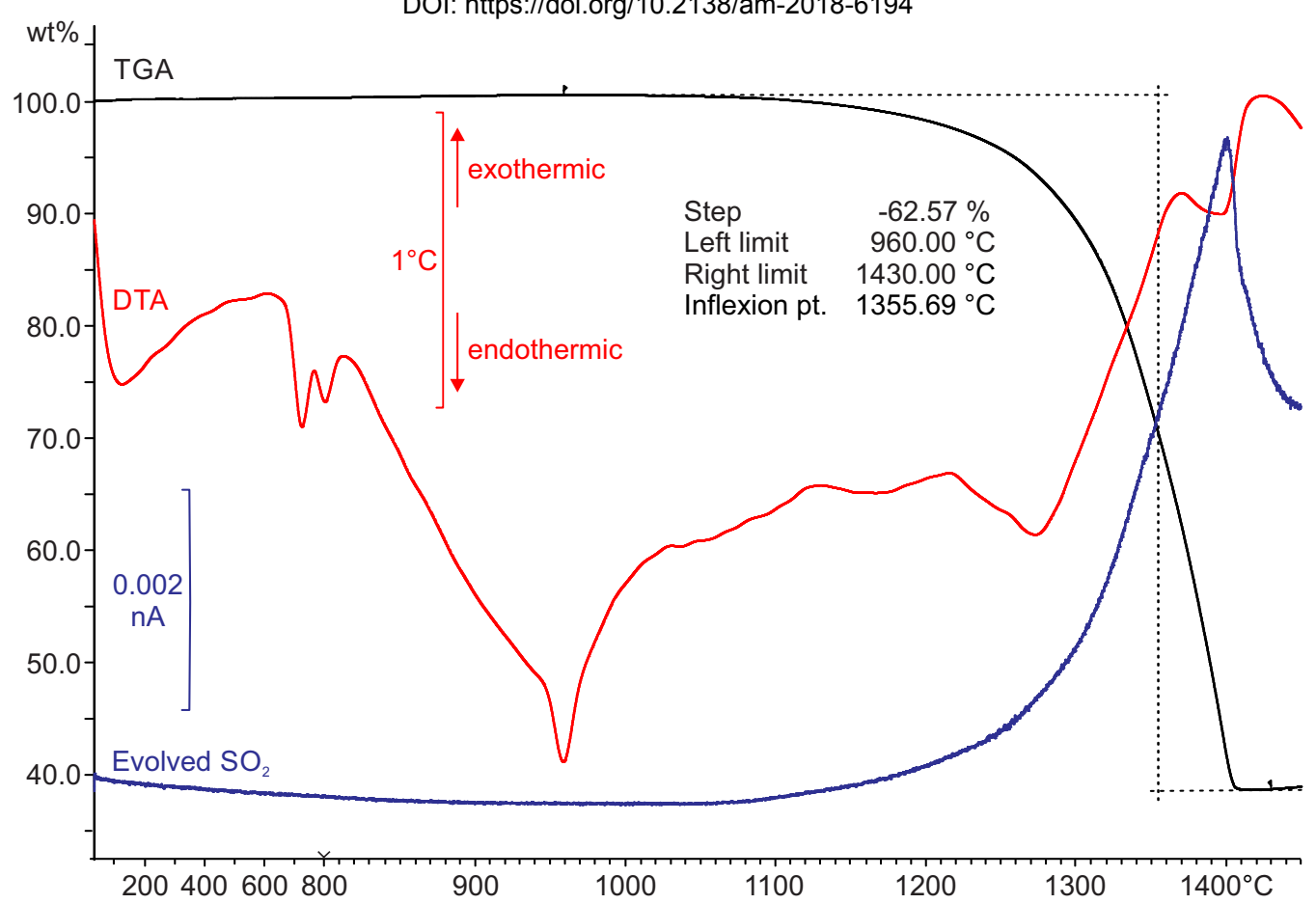

Figure 8

Always consult and cite the final, published document. See http:/www.minsocam.org or GeoscienceWorld 
This is a preprint, the final version is subject to change, of the American Mineralogist (MSA) Cite as Authors (Year) Title. American Mineralogist, in press.

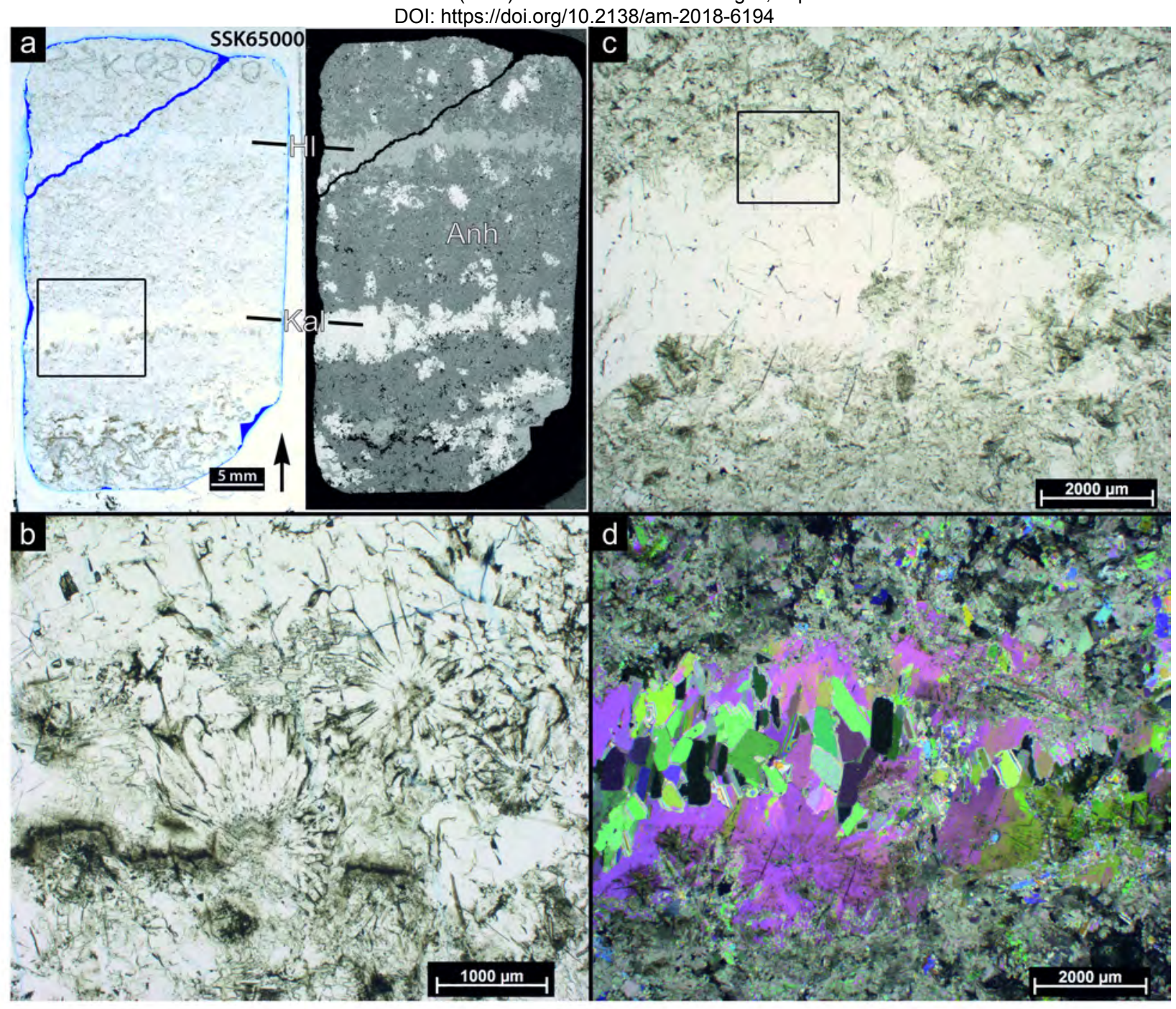


This is a preprint, the final version is subject to change, of the American Mineralogist (MSA) Cite as Authors (Year) Title. American Mineralogist, in press. DOI: https://doi.org/10.2138/am-2018-6194

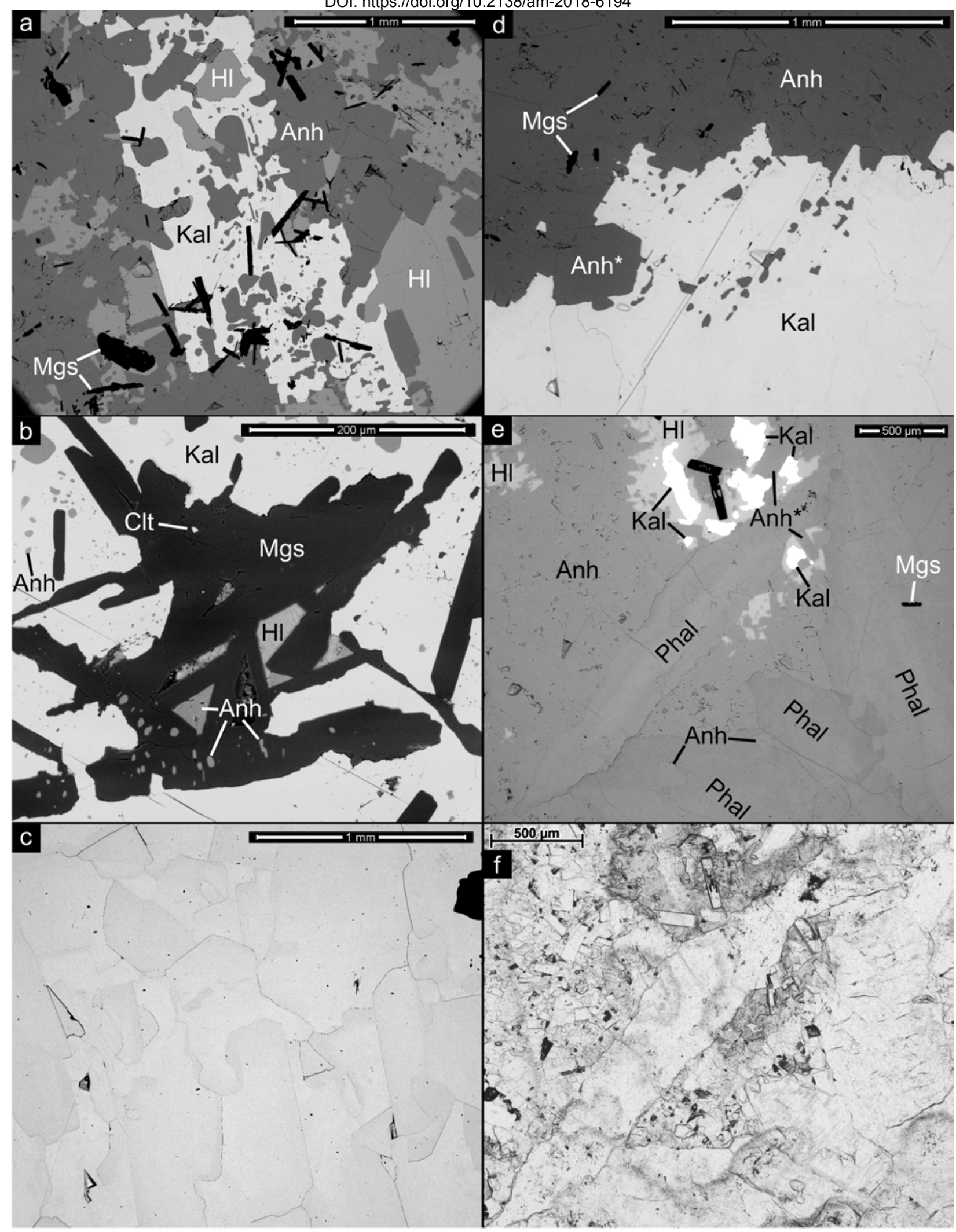

Figure 10 
This is a preprint, the final version is subject to change, of the American Mineralogist (MSA) Cite as Authors (Year) Title. American Mineralogist, in press.

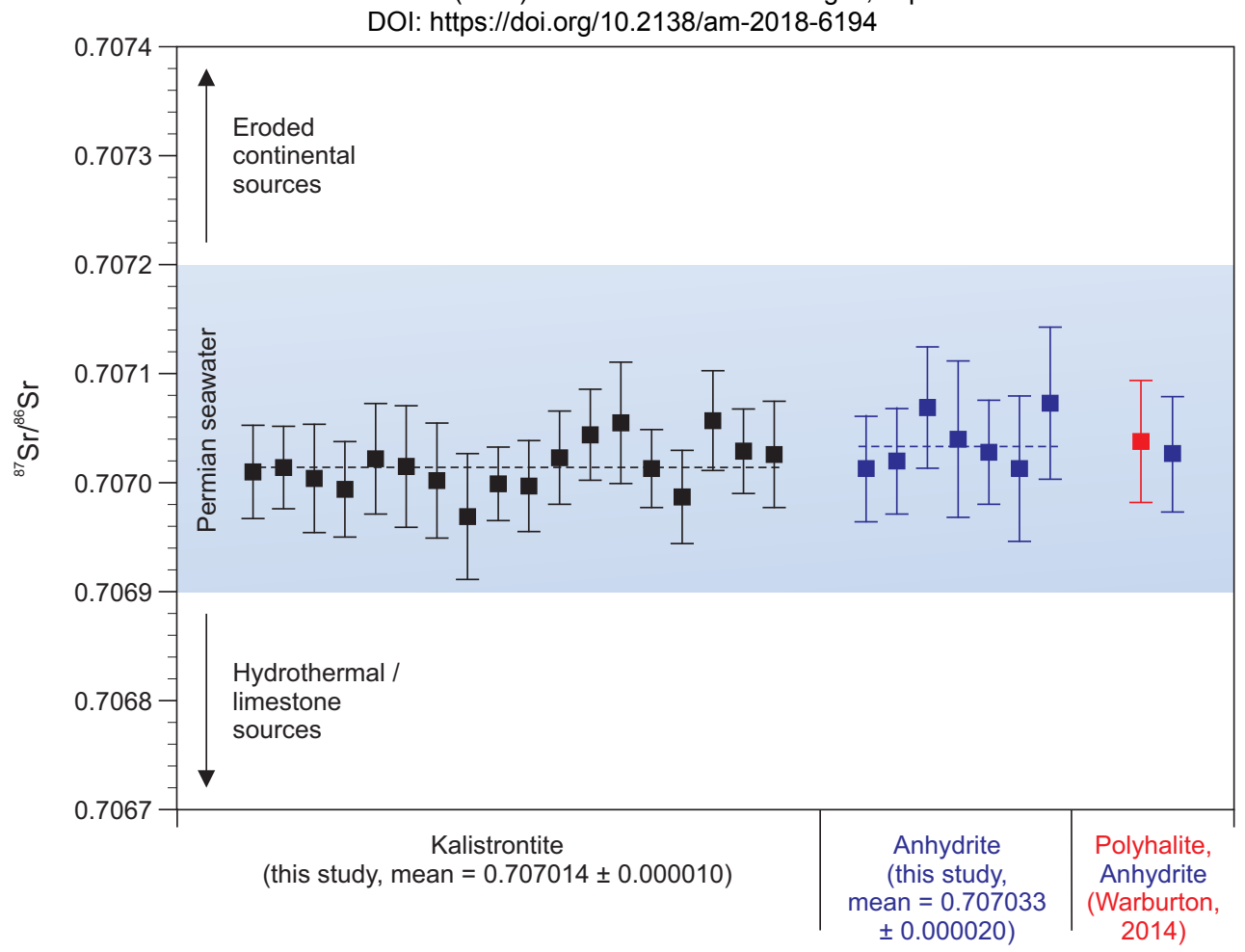

Figure 11

Always consult and cite the final, published document. See http:/www.minsocam.org or GeoscienceWorld 
This is a preprint, the final version is subject to change, of the American Mineralogist (MSA) Cite as Authors (Year) Title. American Mineralogist, in press.

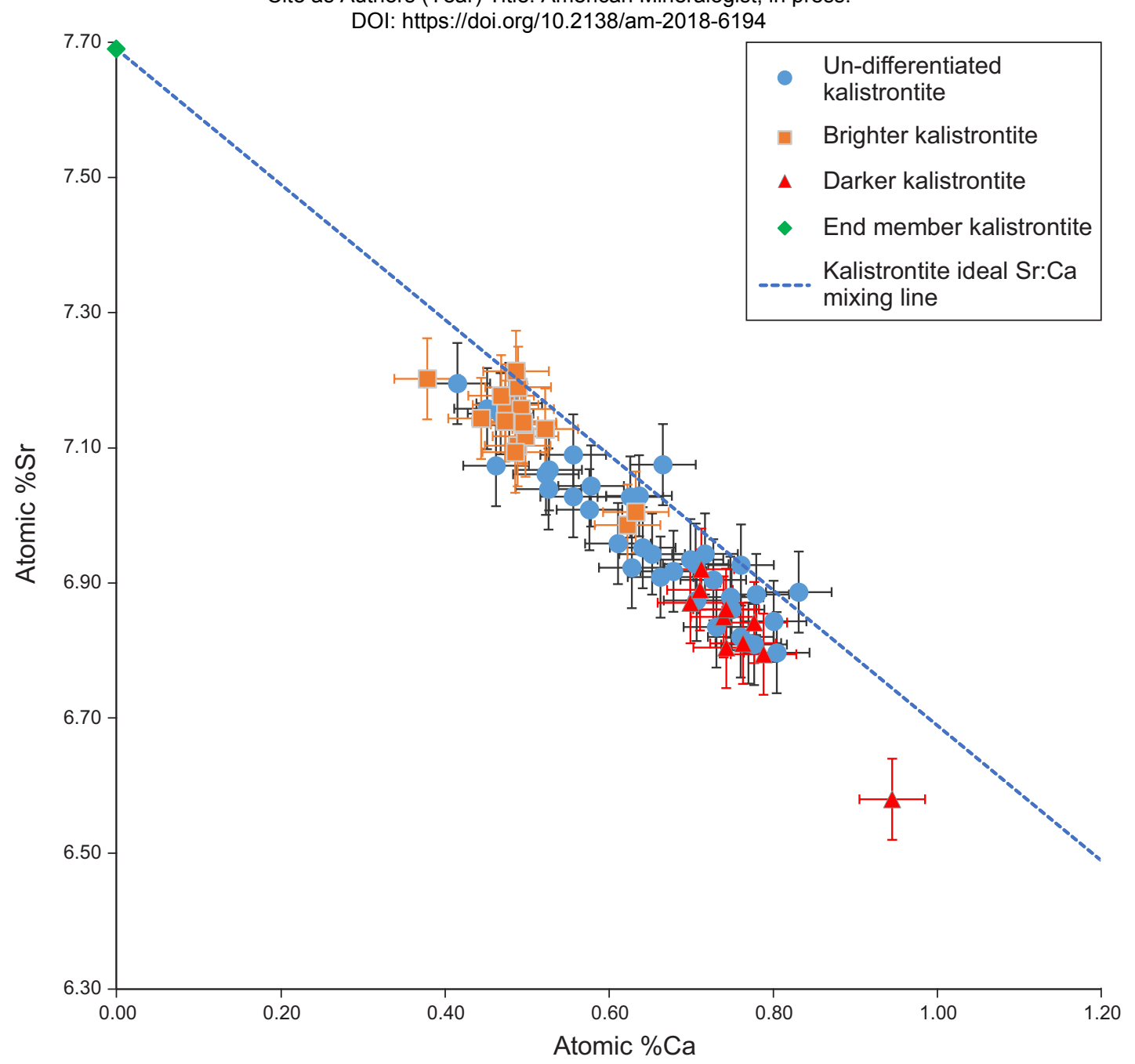

Figure 12

Always consult and cite the final, published document. See http:/www.minsocam.org or GeoscienceWorld 